\title{
Metabotropic Glutamate Receptor Activation in Cerebellar Purkinje Cells as Substrate for Adaptive Timing of the Classically Conditioned Eye-Blink Response
}

\author{
John C. Fiala, Stephen Grossberg, and Daniel Bullock \\ Departmenl of Cognilive and Neural Systems, Boston University, Boston, Massachusetts 02215-2411
}

To understand how the cerebellum adaptively times the classically conditioned nictitating membrane response (NMR), a model of the metabotropic glutamate receptor (mGluR) second messenger system in cerebellar Purkinje cells is constructed. In the model, slow responses, generated postsynaptically by mGluR-mediated phosphoinositide hydrolysis and calcium release from intracellular stores, bridge the interstimulus interval (ISI) between the onset of parallel fiber activity associated with the conditioned stimulus (CS) and climbing fiber activity associated with unconditioned stimulus (US) onset. Temporal correlation of metabotropic responses and climbing fiber signals produces persistent phosphorylation of both AMPA receptors and $\mathrm{Ca}^{2+}$-dependent $\mathrm{K}^{+}$channels. This is responsible for longterm depression (LTD) of AMPA receptors. The phosphorylation of $\mathrm{Ca}^{2+}$-dependent $\mathrm{K}^{+}$channels leads to a reduction in baseline membrane potential and a reduction of Purkinje cell population firing during the CS-US interval. The Purkinje cell firing decrease disinhibils cerebellar nuclear cells, which then produce an excitatory response corresponding to the learned movement. Purkinje cell learning times the response, whereas nuclear cell learning can calibrate it. The model reproduces key features of the conditioned rabbit NMR: Purkinje cell population response is timed properly; delay conditioning occurs for ISIs of up to $4 \mathrm{sec}$, whereas trace conditioning occurs only at shorter ISIs; mixed training at two different ISIs produces a doublepeaked response; and ISIs of 200-400 msec produce maximal responding. Biochemical similarities between timed cerebellar learning and photoreceptor transduction, and circuit similarities between the timed cerebellar circuit and a timed dentate-CA3 hippocampal circuit, are noted.

Key words: classical conditioning; nictitating membrane response; cerebellum; long-term depression; metabotropic glutamate receptors; AMPA receptors; neural network
The cerebellum is involved in the learned timing of classically conditioned eye blinks. Maladaptively timed conditioned responses (CRs) occur after cerebellar cortical lesions (McCormick and Thompson, 1984; Perrett et al., 1993). Neural activity patterns in cerebellar Purkinje cells and interpositus nuclear cells precede and model the CR (McCormick et al., 1982; Thompson and Krupa, 1994). Direct stimulation of mossy fiber inputs to the cerebellum can substitute for external conditioned stimulus (CS) presentation, whereas direct stimulation of the source of climbing fibers can serve as the unconditioned stimulus (US) (Steinmetz et al., 1989). Classical conditioning with direct brain stimulation results in an adaptively timed CK and a correspondingly timed increase in interpositus activity (Steinmetz, 1990b).

A number of mcchanisms have bcen proposed to explain timing of eye blinks, including delay lines (Zipser, 1986; Moore et al., 1989), slow responses in neurons (Grossberg and Schmajuk, 1989; Bartha et al., 1991; Grossberg and Merrill, 1992, 1996; Jaffe, 1992; Bullock et al., 1994), and temporal evolution of the network activity pattern (Chapeau-Blondeau and Chauvet, 1991; Buono-

\footnotetext{
Received Oct. 18, 1995; revised March 1, 1996; accepted March 4, 1996.

This research was supported in part by the Advanced Research Projects Agency (ONR N00014-92-J-4015) and the Office of Naval Research (ONR N00014-92-J1309 and N00014-95-1-0409) to J.C.F.; the Air Force Office of Scientific Research (AFOSR F49620-92-J-0225), the National Science Foundation (NSF IRI-90-24877), and the Office of Naval Research (ONR N00014-92-J-1309 and N00014-95-1-0409) to S.G.; and the National Science Foundation (NSF IRI-90-24877) and the Office of Naval Research (ONR N00014-92-J-1309 and N00014-95-1-0409) to D.B.

Correspondence should be addressed to Professor Stephen Grossberg, Department of Cognitive and Neural Systems, Boston University, 677 Beacon Street, Boston, MA 02215-2411.

Copyright $\bigcirc 1996$ Society for Neuroscience $\quad 0270-6474 / 96 / 163760-15 \$ 05.00 / 0$
}

mano and Mauk, 1994). Given that eye blinks may be delayed for up to $4 \mathrm{sec}$ after onset of the CS (Gormezano, 1966), there do not seem to be delay lines of sufficient length in cerebellar cortex (Freeman, 1969). Noise in network activity pattern models seem to preclude their operation over these long intervals as well (Bounomano and Mauk, 1994). The most likely candidate mechanism is a slow neuron response. Given the above evidence that timing occurs in cerebellar cortex and the fact that granule cells seem to have only short latency responses (Thompson and Bower, 1993), the simplest explanation is that slow responses in Purkinje cells are the operative mechanism in adaptive timing. We hypothesize that Purkinje cell slow responses are produced by activation of metabotropic glutamate receptors (mGluRs) and that the latency of the $\mathrm{mGluR}$ response spans the range of conditionable eye-blink interstimulus intervals (ISIs).

Experimental study of metabotropic responses in Purkinje cells is difficult. Slow excitatory postsynaptic potentials mediated by mGluRs have been observed in some preparations (Batchelor and Garthwaite, 1993; Batchelor et al., 1994) but not in others (Miyakawa et al., 1992; Midtgaard et al., 1993; Eilers et al., 1995). This difficulty may be related to the fact that the endoplasmic reticulum (ER) is reorganized rapidly in Purkinje cells after perfusion with artificial media such that normal release of calcium from intracellular stores is blocked (Takei et al., 1994). In the present study, the basic hypothesis was tested by constructing a mathematical model of the mGluR response in Purkinje cells. Simulations of the model demonstrate how adaptive mechanisms within Purkinje cells can produce a temporal regulation of the firing rate of these cells that times the disinhibition of interpositus 


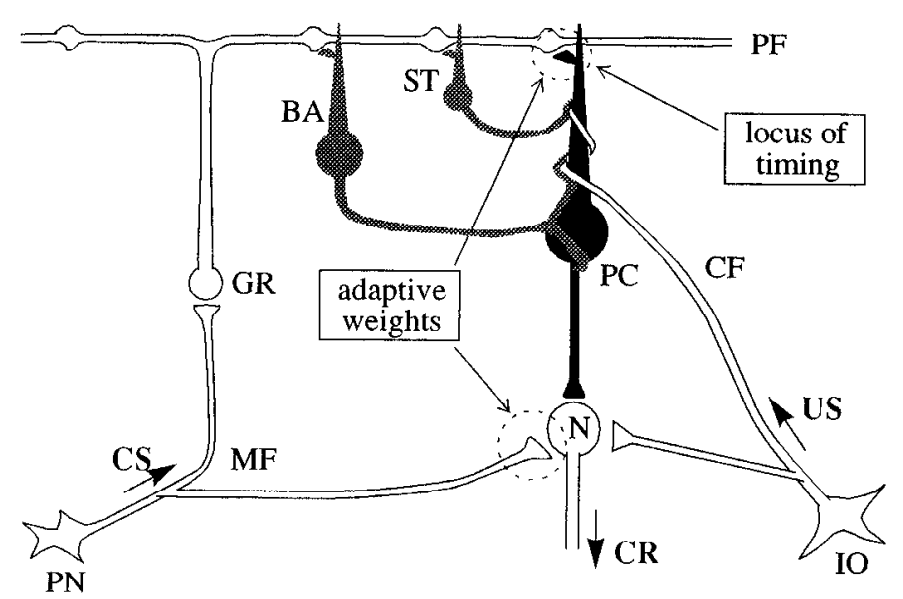

Figure 1. Basic neuronal circuitry of the cerebellum that forms the basis for the present model of adaptive timing of eye blinks. Inhibitory neurons, dark; excitatory neurons, white. $P C$, Purkinje cell; $B A$, basket cell; $S T$, stellate cell; $G R$, granule cell; $P F$, parallel fiber; $M F$, mossy fiber; $C F$, climbing fiber; $N$, cercbellar nuclear cell; $P N$, precerebellar neuron that issues mossy fibers; $I O$, inferior olive; $C S$, conditioned stimulus; $C R$, conditioned response; US, unconditioned stimulus.

nuclear cells and thereby "opens a timed gate" that enables gains learned at the nuclear stage to modulate ongoing movements (Fig. 1). The model suggests new experiments that can be used to test which metabotropic pathways influence the learned timed response.

\section{MATHEMATICAL MODEL}

\section{The biochemistry of adaptively timed cerebellar learning}

The present work develops a model that links behavioral properties of adaptively timed classical conditioning to the biochemistry and biophysics of metabotropic glutamate responses in the cerebellum. A key paradigm for studying cerebellar classical conditioning is the rabbit nictitating membrane response (NMR). The NMR can be delay- or trace-conditioned to an auditory, vibrolactual, or light CS (Gormezano, 1966). The CS usually is paired with a periorbital shock or air-puff US. To reach the same level of performance, trace conditioning, in which the CS terminates before US onset, requires five times as many learning trials as delay conditioning, in which the CS and US overlap in time. Asymptotic performance levels of $95-98 \%$ CRs can be obtained within three or four delay-conditioning sessions, each consisting of $50-60$ CS-US pairings with an ISI of $250 \mathrm{msec}$ and an intertrial interval of $1 \mathrm{~min}$. The amplitude of individual CRs is correlated positively with the frequency of CRs. The more generic term strength of $C R$ is used to refer to either amplitude of individual CRs or CR frequency.

An individual CR has a distinctive topography with a number of timing-related properties. The CR is timed adaptively such that the peak amplitude occurs near the expected onset of the US. CR onset is smooth, such that the CR onset typically occurs much before expected onset of the US. The CS must precede the US by more than 50 msec for successful conditioning (Smith et al., 1969). The onset of the CS can precede the US by up to $4 \mathrm{sec}$ in delay conditioning (Gormezano, 1966), whereas trace conditioning cannot be obtained when the CS precedes the US by $>2$ sec (Solomon et al., 1986). The strength of the CR depends on the ISI, the time between onset of CS and onset of US, in a characteristic way. CR strength is maximal at ISIs of $200-400 \mathrm{msec}$ and is

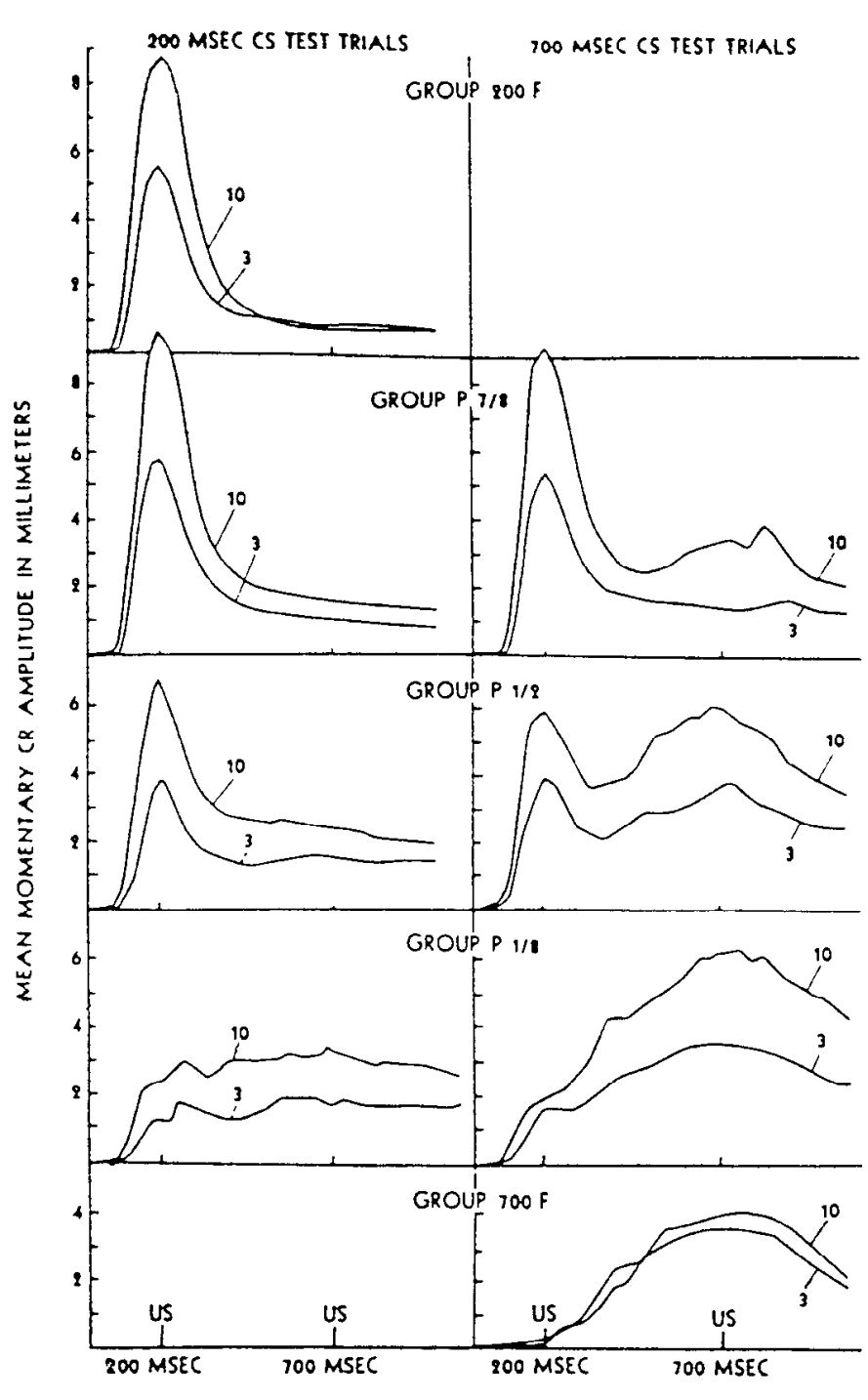

Figure 2. NMRs after mixed ISI delay conditioning. Group $200 \%$ received all $200 \mathrm{msec}$ ISI trials. Group P $n / 8$ received mixed trials in a ratio of $n 200$ msec to $8-n 700 \mathrm{msec}$ ISI trials. Group $700 \mathrm{~F}$ received all $700 \mathrm{msec}$ ISI trials. As shown in the right-hand column, $700 \mathrm{msec}$ CS test trials result in double-responding. (Reprinted with permission from Millenson et al., 1977.)

reduced at shorter or longer ISIs (Smith et al., 1969). This property traditionally is referred to as the inverted- $U$ property of the $\mathrm{CR}$. The strength of CRs diminishes more quickly as a function of long ISIs for trace versus delay conditioning.

When the NMR is conditioned to a particular $\mathrm{ISI}_{1}$, such that the peak response occurs at that time, continued conditioning to a different ISI $_{2}$ will produce a discrete peak shift in which the response peak at ISI $_{1}$ diminishes and a new response peak grows at ISI $_{2}$ (Coleman and Gormezano, 1971). Alternating between two different ISIs during training with a single CS will produce a double-peaked CR (Fig. 2), each peak coincident with one of the ISIs (Hoehler and Leonard, 1976; Millenson et al., 1977).

The cerebellum has been posited as a locus of conditioned NMR timing (Perrett et al., 1993). A properly timed neural expression of the CR occurs in the interpositus nucleus of the cerebellum, as revealed by electrophysiological recordings (McCormick et al., 1982; Steinmetz, 1990b). Interpositus neurons exhibit a firing pattern that resembles the conditioned NMR 


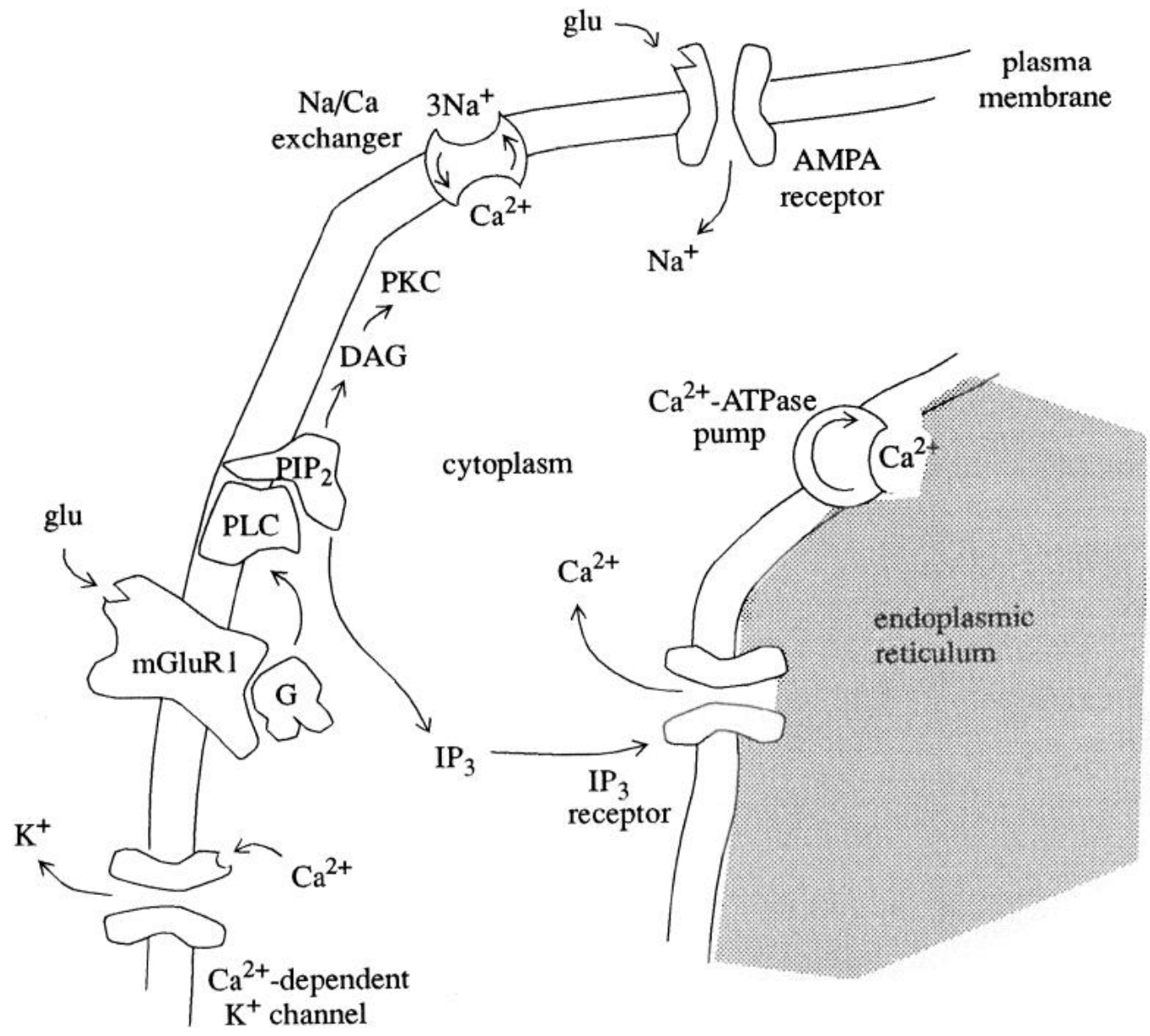

Figure 3. Components of the metabolic transmission pathway within a Purkinje cell dendrite. $D A G$, Diacylglycerol; $G$, guanine nucleotide-binding protein; $g l u$, glutamate; $m$ GluRl, metabotropic glutamate receptor subtype $1 ; P K C$, protein kinase $\mathrm{C} ; P L C$, phospholipase $\mathrm{C}$; $P I P_{2}$, phosphatidylinositol 4,5-bisphosphate; $I P_{3}$, inositol 1,4,5-trisphosphate. topography; however, interpositus responses precede the NMR by 50 msec or more (Thompson and Krupa, 1994). Such a temporal precedent is required if the interpositus is the originator of the response and the slow muscle-plant system is to produce eyelid closure that peaks at US onset (Bartha and Thompson, 1992a,b).

Direct stimulation of inputs to cerebellum can substitute for external CS presentation during conditioning of an adaptively timed response in the cerebellum. An auditory CS (tone) normally activates the cerebellum via mossy fibers that originate in the pontine nuclei (Steinmetz et al., 1987). Conditioning with direct stimulation of mossy fibers as the CS results in properly timed CRs (Steinmetz et al., 1986). The ISI may be as long as $2000 \mathrm{msec}$ or as short as $100 \mathrm{msec}$, and CRs may peak near the time of the expected US (Steinmetz, 1990a). Interpositus expression of the $\mathrm{CR}$ has the same timing properties in conditioning with direct brain stimulation as when peripheral stimulation is used (Steinmetz, 1990b). This evidence suggests strongly that a delayed response to the CS can be generated by the cerebellar network.

Earlier work has developed lumped neural models of how adaptive timing of neural responses may occur. These models have successfully simulated key properties of timed behavior and neural spiking and have given credence to the hypothesis that adaptive timing is produced by selective enhancement of certain responses from an entire spectrum of responses distributed through time (Grossberg and Schmajuk, 1989; Grossberg and Merrill, 1992). The present work has used these model properties as a point of departure for interpreting and modeling biochemical properties of Purkinje cells in the cerebellar cortex that are consistent with the behavioral and neural data. In the model, the
CS activates mGLUR responses that are used for spectral timing in eye-blink conditioning. The CS does this by activating mossy fibers, which in turn activate granule cells whose parallel fibers synapse on Purkinje cells (Fig. 1). The mGluRs are located just outside of the synaptic junction with parallel fiber terminals (Nusser et al., 1994).

\section{Metabotropic response model}

Purkinje cells of the cerebellar cortex express mGluRs of the subtype mGluR1 (Fig. 3). Releases of glutamate from parallel fiber terminals activate mGluR1 receptors by binding to the receptor (Blackstone et al., 1989). The activated receptor binds the G-protein/GDP complex, which promotes the exchange of GTP for GDP and cleavage of the G-protein into $\alpha$ and $\beta \gamma$ components (Berstein et al., 1992). The $\mathrm{G}_{\alpha}$ component of the G-protein diffuses to phospholipase C (PLC) in the cell membrane and enables its enzymatic activity. Activated PLC $\left(\mathrm{PLC} \cdot \mathrm{G}_{\alpha} \cdot \mathrm{GTP}\right)$ catalyzes the production of the second messengers inositol trisphosphate $\left(\mathrm{IP}_{3}\right)$ and diacylglycerol (DAG) from phosphatidylinositol 4,5-bisphosphate $\left(\mathrm{PIP}_{2}\right)$ (Blackstone et al., 1989). IP $_{3}$ diffuses through the cytoplasm to the membrane of the ER. $\mathrm{IP}_{3}$ binds to receptors in this membrane $\left(\mathrm{IP}_{3} \mathrm{R}\right)$, opening calcium channels and allowing $\mathrm{Ca}^{2+}$ to flow into the cytoplasm. The rapid increase of the cytosolic calcium concentration activates a $\mathrm{Ca}^{2+}$-dependent $\mathrm{K}^{+}$conductance, which leads to hyperpolarization and a decrease in excitability (Khodakhah and Ogden, 1993).

The binding of glutamate to mGluR exhibits first-order kinetics with a Hill coefficient of 1 and $K_{\mathrm{d}}$ of $0.296 \mu \mathrm{M}$ (Thomsen et al., 
1993). With the inclusion of an inactivated state, the time course of mGluR activation is modeled by:

$$
\frac{d B}{d t}=k_{1}\left(B_{\max }-A-B\right)[g l u]-0.296 k_{1} B-k_{2} B C
$$

and

$$
\frac{d A}{d t}=k_{2} B C-k_{3} A
$$

where $B$ is the concentration of bound, activated receptor, $B_{\max }$ is the concentration of available receptors, and $A$ is the concentration of inactivated receptors; $[g l u]$ is the concentration of glutamate to which the receptors are exposed as a result of CS input. The calcium- and DAG-dependent protein kinase, protein kinase $\mathrm{C}(\mathrm{PKC})$, regulates the inactivation of receptors and the G-protein-mediated responsc (Nakanishi, 1988; Catania et al., 1991; Herrero et al., 1994; Yarfitz and Hurley, 1994). Protein kinase $\mathrm{C}$ activity in the model is given by the variable $C$ (below).

Activated mGluRs stimulate the activation of G-proteins. The rate of $\mathrm{G}$-protein activation increases linearly with the concentration, $B$, of activated receptors (Berstein et al., 1992). The concentration of activated G-proteins is given by the variable $G$ :

$$
\frac{d G}{d t}=k_{4}\left(G_{\max }-G\right) B-k_{5} G-k_{6} G C .
$$

The final term represents G-protein inactivation by PKC (Nestler and Duman, 1994; Yarfitz and Hurlcy, 1994).

In addition to PLC activity dependent on the presence of activated G-protein, cerebellar membranes contain a form of PIC. activated by cytoplasmic calcium (Mignery et al., 1992). The production of $\mathrm{IP}_{3}$ by PLC is thus modeled by:

$$
\frac{d I}{d t}=\left(I_{\max }-I\right)\left(k_{7} G+k_{8} P L C\left(\left[\mathrm{Ca}^{2+}\right]_{\text {cyt }}\right)\right)-k_{9} I,
$$

where $I$ is the $\mathrm{IP}_{3}$ concentration. Calcium-dependent PLC activity exhibits a steep dependence on calcium with half-maximal activation in the range of 1-20 $\mu \mathrm{M}$ (Homma et al., 1988; Mignery et al., 1992). Therefore we chose a Hill coefficient of 2 and $K_{\mathrm{d}}$ of $20 \mu \mathrm{M}$ for this PLC activation:

$$
P L C\left(\left[\mathrm{Ca}^{2+}\right]_{\mathrm{cyl}}\right)=\frac{\left[\mathrm{Ca}^{2+}\right]_{\mathrm{cyt}}^{2}}{\left[\mathrm{Ca}^{2+}\right]_{\mathrm{cyt}}^{2}+20.0} .
$$

DAG is produced in conjunction with $\mathrm{IP}_{3}$ by $\mathrm{PIP}_{2}$ hydrolysis. Therefore the amount, $D$, of DAG is given by:

$$
\frac{d D}{d t}=\left(D_{\max }-D\right)\left(k_{7} G+k_{8} P L C\left(\left[\mathrm{Ca}^{2+}\right]_{\mathrm{cyt}}\right)\right)-k_{9} D
$$

PKC is activated by binding a calcium ion and DAG (Schwartz and Kandel, 1991), as in:

$$
\frac{d C}{d t}=k_{10}\left(C_{\max }-C\right) D\left[\mathrm{Ca}^{2+}\right]_{\mathrm{cyt}}-k_{11} C .
$$

$\mathrm{IP}_{3}$ binding to $\mathrm{IP}_{3} \mathrm{R}$ in ER membrane is one-to-one with halfmaximal binding at 100-300 nм (Joseph et al., 1989; Watras et al., 1991; Missiaen et al., 1994). Assuming that this reaction is fast compared with other reactions in the model yields as a formula for the fraction of bound receptors:

$$
R=\frac{I}{I+0.2}
$$

$\mathrm{IP}_{3}$ binding is required to open the $\mathrm{IP}_{3} \mathrm{R}$ calcium channels and release calcium into the cytosol, but channel opening also demonstrates a biphasic dependence on the cytosolic concentration of calcium (Joseph et al., 1989; Iino, 1990; Bezprozvanny et al., 1991). A similar biphasic calcium dependence is seen in the ryanodine-sensitive calcium channels of endoplasmic and sarcoplasmic reticulum (Meissner et al., 1986; Bezprozvanny et al., 1991). A fragmentary sequence homology between the ryanodine receptor $(\mathrm{RyR})$ and $I \mathrm{P}_{3} \mathrm{R}$ underlies the functional similarities of these channels (Furuichi and Mikoshiba, 1995). RyR and $\mathrm{IP}_{3} \mathrm{R}$ contain at least two types of binding sites for $\mathrm{Ca}^{2+}$ or $\mathrm{Ca}^{2+}$. activated proteins, one stimulating channel opening and another inhibiting it (Chen et al., 1992; Chen and MacLennan, 1994).

We model $\mathrm{IP}_{3} \mathrm{R}$ kinetics with six states:

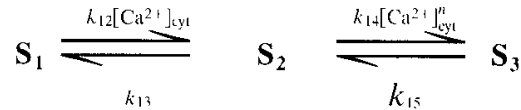

$$
\begin{aligned}
& k^{-}\left\|k^{+} \mathrm{IP}_{3} \quad k^{-} \quad\right\| \quad k^{+} \mathrm{IP}_{3} \quad k^{-} \| k^{+} \mathrm{IP}_{3}
\end{aligned}
$$

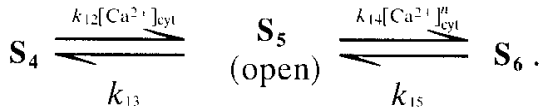

Here, $\left\{S_{2}, S_{5}\right\}$ represents the receptor with $\mathrm{Ca}^{2+}$ bound to the stimulating site and $\left\{S_{3}, S_{6}\right\}$ with $\mathrm{Ca}^{2+}$ bound to the inhibitory site. The cooperativity of the later binding produces a Hill coefficient of $n=1.65$ (Meissner et al., 1986). By considering $\mathrm{IP}_{3}$ binding to be at equilibrium with respect to the $\mathrm{Ca}^{2+}$ binding reactions, the channel kinetics are described by two differential equations:

$$
\begin{gathered}
\frac{d R_{\mathrm{u}}}{d t}=k_{12}\left(R_{\mathrm{max}}-R_{\mathrm{o}}-R_{l}\right)\left[\mathrm{Ca}^{2+}\right]_{\mathrm{cyt}}+k_{15} R_{t}-k_{13} R_{\mathrm{o}} \\
-k_{14} R_{\mathrm{o}}\left[\mathrm{Ca}^{2+}\right]_{\mathrm{cyt}}^{n}, \\
\frac{d R_{t}}{d t}=k_{14} R_{\mathrm{o}}\left[\mathrm{Ca}^{2+}\right]_{\mathrm{cyt}}^{n}-k_{15} R_{l} .
\end{gathered}
$$

The channel open state is $R_{o}$, and $R_{\mathrm{i}}$ is the channel inhibited (closed) by calcium binding. At steady state, the open probability is:

$$
P_{\mathrm{o}}=R_{\max }\left(\frac{I}{I+0.2}\right)\left(\frac{\frac{k_{15}}{k_{14}}\left[\mathrm{Ca}^{2+}\right]_{\mathrm{cyt}}}{\left[\mathrm{Ca}^{2+}\right]_{\mathrm{cyt}}^{\prime \prime 1}+\frac{k_{15}}{k_{14}}\left[\mathrm{Ca}^{2+}\right]_{\mathrm{cyt}}+\frac{k_{13} k_{15}}{k_{12} k_{14}}}\right) .
$$

With proper choice of parameters, this model is in agreement with the open probability data of Bezprozvanny et al. (1991), as shown in Figure 4.

As depicted in Figure 3, the cytoplasmic calcium concentration in Purkinje cells is regulated by two transport systems, a $\mathrm{Na} / \mathrm{Ca}$ exchanger in the plasmalemma (Staub et al., 1992) and a $\mathrm{Ca}^{2+}$ ATPase pump in the reticular membrane (Villa et al., 1991; Takei et al., 1992). The exchanger has a low affinity for cytosolic $\mathrm{Ca}^{2+}$ $(1-10 \mu \mathrm{M})$ but a high capacity, whereas the ATPase pump has a 


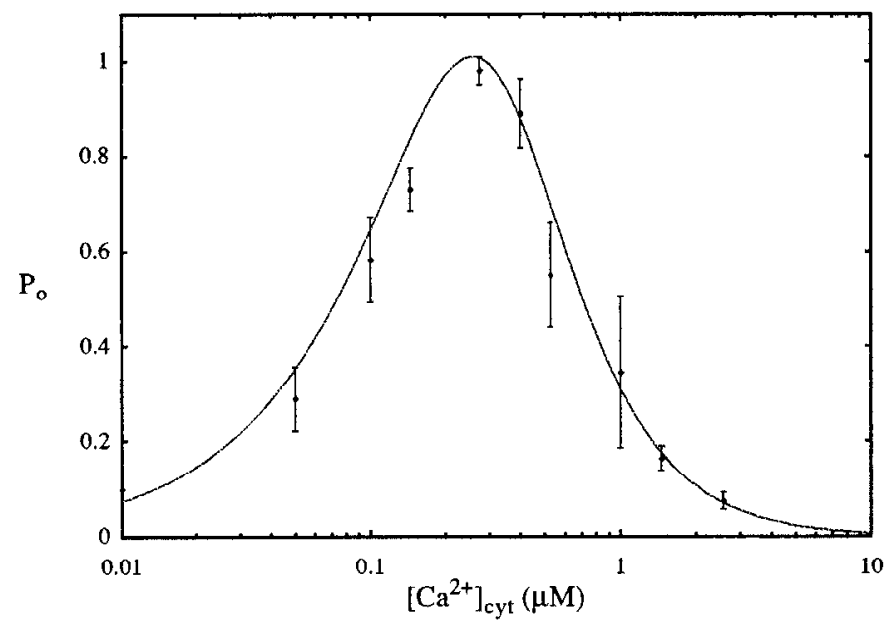

Figure 4. Open probability of $I \mathrm{P}_{3} \mathrm{R}$ in model (dashed line) and in experiments with $\mathrm{IP}_{3} \mathrm{R}$ reconstituted into planar lipid bilayers (Bezprozvanny et al., 1991) in the presence of $2 \mu \mathrm{M} \mathrm{IP}_{3}$. Normalized from maximum open probability of $15 \%$. Model parameter values: $R_{\max }=1, k_{13} / k_{12}=0.81$, $k_{15} / k_{14}=0.0556, n=1.65$.

smaller capacity and a much higher affinity $(0.2 \mu \mathrm{M})$ (Yamada et al., 1989). The ATPase pump in reticular membrane exhibits a cooperativity of two calcium ions per transfer (De Meis and Inesi, 1982), and the calcium flux thus can be characterized by a Hill equation of the form:

$$
\frac{\left[\mathrm{Ca}^{2+}\right]_{\mathrm{cyt}}^{2}}{\left[\mathrm{Ca}^{2+}\right]_{\mathrm{cyt}}^{2}+0.2} .
$$

The exchanger is at equilibrium when (Carafoli, 1987):

$$
\left[\mathrm{Ca}^{2+}\right]_{\mathrm{cyt}}=c_{0}=\left[\mathrm{Ca}^{2+}\right]_{\mathrm{ext}}\left(\frac{\left[\mathrm{Na}^{+}\right]_{\mathrm{cyt}}}{\left[\mathrm{Na}^{+}\right]_{\mathrm{cxt}}}\right)^{3} \exp \left(\frac{V F}{R T}\right),
$$

where ext denotes extracellular ion concentrations, $V$ is plasma membrane potential, $F$ is the Faraday constant, $R$ is the gas constant, and $T$ is thermodynamic temperature. Assuming the other ionic concentrations are relatively constant, the $\mathrm{Ca}^{2+}$ flux produced by the exchanger is proportional to (Hodgkin and Nunn, 1987):

$$
\frac{\left[\mathrm{Ca}^{2+}\right]_{\mathrm{cyl}}-c_{0}}{2+\left[\mathrm{Ca}^{2+}\right]_{\mathrm{cyt}}-c_{0}},
$$

where $c_{0}$ is the equilibrium concentration, above, and $2 \mu \mathrm{M}$ is the half-activation point.

Therefore, by Lquations $9-10$ and $12-14$, the cytoplasmic calcium concentration can be described by:

$$
\begin{aligned}
\frac{d\left[\mathrm{Ca}^{2+}\right]_{\mathrm{cyt}}}{d t} & =k_{16} R_{\mathrm{o}}\left(\frac{I}{I+0.2}\right)\left(\left[\mathrm{Ca}^{2+}\right]_{\mathrm{ER}}-\left[\mathrm{Ca}^{2+}\right]_{\mathrm{cyt}}\right) \\
& -k_{17}\left(\frac{\left[\mathrm{Ca}^{2+}\right]_{\mathrm{cyt}}^{2}}{\left[\mathrm{Ca}^{2+}\right]_{\mathrm{cyt}}^{2}+0.2}\right)-k_{18}\left(\frac{\left[\mathrm{Ca}^{2+}\right]_{\mathrm{cyt}}-c_{0}}{2+\left[\mathrm{Ca}^{2+}\right]_{\mathrm{cyt}}-c_{0}}\right) .
\end{aligned}
$$

We assume that calcium flux into the cytoplasm from the ER does not produce a significant change in the concentration of free $\mathrm{Ca}^{2+}$ in the lumen. Although the concentration of free $\mathrm{Ca}^{2+}$ in $\mathrm{ER}$ is not known, total calcium is in the range of 4-10 mM (Baumann et al., 1991).

The intracellular calcium response affects the Purkinje cell membrane potential. Two conductances are principally involved: a depolarizing conductance attributable to the electrogenic nature of the $\mathrm{Na} / \mathrm{Ca}$ exchanger (Glaum et al., 1992; Staub et al., 1992) and a hyperpolarizing $\mathrm{Ca}^{2+}$-dependent $\mathrm{K}^{+}$-conductance (Fagni et al., 1991; Khodakhah and Ogden, 1993). Because adequate data on the $\mathrm{Ca}^{2+}$-dependent $\mathrm{K}^{+}$-conductance in Purkinje cells are not available (De Schutter and Bower, 1994a), our model is derived from data on the mGluR-activated $\mathrm{Ca}^{2+}$. dependent $\mathrm{K}^{+}$-conductance in cultured cerebellar granule cells (Fagni et al., 1991).

As shown in Figure $5 A$, the dependency of open probability on voltage follows the Boltzmann relation with an $e$-fold change in $P_{\mathrm{o}}$ per $22.5 \mathrm{mV}$. The half-activation values $\left(V_{0}\right)$ of this equation vary linearly with the $\log$ of the cytoplasmic calcium concentration. Fitting a straight line to the data of Figure $5 A$ gives:

$$
V_{0}=11-134 \log \left[\mathrm{Ca}^{2+}\right]_{\mathrm{cyt}}
$$

where voltage is given in millivolts and calcium concentration in micrometers. (A similar relation holds for $\mathrm{Ca}^{2+}$-dependent $\mathrm{K}^{+}$ channels in other preparations; Bielefeldt and Jackson, 1994.) Combining this result with the Boltzmann relation gives an expression for channel opening in terms of calcium concentration and membrane potential (Fig. 5B):

$$
g_{K}\left(\left[\mathrm{Ca}^{2+}\right]_{\mathrm{cyt}}, V\right)=\frac{\left[\mathrm{Ca}^{2+}\right]_{\mathrm{cyt}}^{2.6}}{\left[\mathrm{Ca}^{2+}\right]_{\mathrm{cyt}}^{2.6}+\exp \left(\frac{11-V}{22.5}\right)} .
$$

The reversal potential of Purkinje cell potassium channels is $\sim-85 \mathrm{mV}$ (De Schutter and Bower, 1994a). Thus, incorporating the calcium-driven plasma membrane currents attributable to Equations 14 and 17, membrane potential is:

$$
\begin{array}{r}
\frac{d V}{d t}=k_{19}\left(\frac{\left[\mathrm{Ca}^{2+}\right]_{\mathrm{cyt}}-c_{0}}{2+\left[\mathrm{Ca}^{2+}\right]_{\mathrm{cyt}}-c_{0}}\right)-\bar{g} g_{K}\left(\left[\mathrm{Ca}^{2+}\right]_{\mathrm{cyt}}, V\right)(85+V) \\
+k_{20}\left(V_{b}-V^{r}\right)
\end{array}
$$

where $\bar{g}$ is the peak conductance of the $\mathrm{Ca}^{2+}$-dependent $\mathrm{K}^{+}$ channel. This conductance is modulated through conditioning, as described in the next section.

The baseline membrane potential, $V_{b}$, is used to set an approximate level of tonic activity. It has been observed (De Schutter and Bower, 1994b) that a resting potential of $\sim-68$ $\mathrm{mV}$ as commonly seen in Purkinje cells in vitro gives rise to a quiescent state in which there is little or no tonic simple-spike activity. Purkinje cells in vivo, on the other hand, have a continual background level of parallel fiber activity, which gives them a more depolarized resting potential of $\sim-50 \mathrm{mV}$. This elevated baseline potential gives rise to a state of tonic simplespike firing. We assume that $V_{\mathrm{b}}=-50 \mathrm{mV}$, such that when the $\mathrm{mGluR}$ activation raises intracellular calcium levels, a net increase or decrease in simple-spike firing rate is produced on the basis of whether the $\mathrm{Na} / \mathrm{Ca}$ exchange- and $\mathrm{Ca}^{2+}$-dependent $\mathrm{K}^{+}$-currents depolarize or hyperpolarize the cell.

\section{Learning model}

The processes hypothesized to mediate learning in the present model are depicted in Figure 6, which shows how climbing fiber and parallel fiber signals (top) can affect receptors (bottom) that control transmembrane current. The hypothesis is primarily based on evidence for long-term depression (LTD) of AMPA receptors at the parallel fiber-Purkinje cell synapses (Ito, 1991; Ito and Karachot, 1992). LTD is a result of phosphorylation of AMPA 


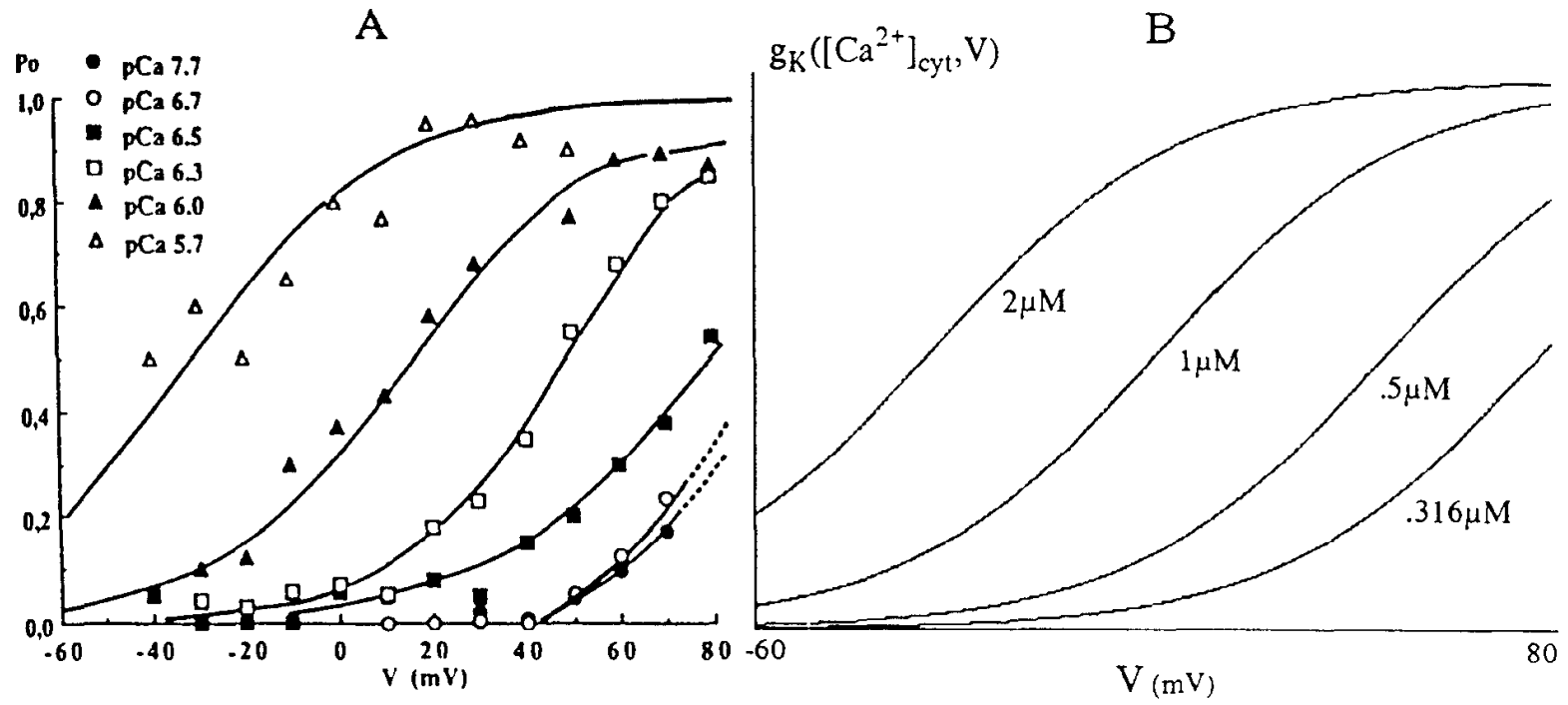

Figure 5. A, Voltage and calcium dependencies of the mGluR-activated $\mathrm{Ca}^{2+}$-dependent $\mathrm{K}^{+}$channels of cultured cerebellar granule cells. (Reprinted with permission from Fagni et al., 1991.) B, Equation 17 plotted as a function of voltage for various cytoplasmic calcium concentrations.

receptors, but there are additional substrates for phosphorylation that also affect the Purkinje cell response, especially the metabotropic response component, as described below.

Stimulation of the mGluR1 receptor activates $\mathrm{PKC}$ by the production of DAG and the release of $\mathrm{Ca}^{2+}$ intracellularly (Nishizuka, 1986). PKC activation is necessary for induction of LTD of AMPA receptors (Linden and Conner, 1991). The mGluR1 receptor must be present (Aiba et al., 1994; Shigemoto et al., 1994) and activated (Linden et al., 1991; Daniel et al., 1992; Hartell, 1994) for LTD to occur; however, Kasono and Hirano (1995) reported recently that an intracellular $\mathrm{IP}_{3}$ increase in conjunction with AMPA-receptor activation and depolarization is sufficient for LTD. Blockage of $\mathrm{IP}_{3}$ binding to $\mathrm{IP}_{3} \mathrm{R}$ (Kasono and Hirano, 1995) or blockage of the intracellular $\mathrm{Ca}^{2+}$ rise (Sakurai, 1990; Konnerth et al., 1992) prevents LTD. Therefore, it seems that the metabotropic second messenger responses in the parallel fiber-activated pathway are important for LTD induction.

Climbing fiber stimulation is the second pathway involved in LTD. Climbing fiber activation strongly depolarizes the Purkinje cell and produces $\mathrm{Ca}^{2+}$ spiking and plateau potentials in the dendrites (Llinás and Sugimori, 1992). It has been proposed that
Figure 6. Processes mediating learning of a timed response in cerebellar Purkinje cells. AMPA, Amino-3-lydlroxy-5-methyl4-isoxazole propionic acid-sensitive glutamate receptor; $c G M P$, cyclic guanosine monophosphate; $D A G$, diacylglycerol; glu, glutamate; $G C$, guanylyl cyclase; $g_{\mathrm{K}}, \mathrm{Ca}^{2+}$. dependent $\mathrm{K}^{+}$channel protein; GTP, guanosine triphosphate; $I P_{3}$, inositol $1,4,5$ trisphosphate; $N O$, nitric oxide; $N O S$, nitric oxide synthase; $P$, phosphate; $P L C$, phospholipase $\mathrm{C}$; $P K C$, protein kinase $\mathrm{C}$; $P K G$, cGMP-dependent protein kinase; $P P-1$, protein phosphatase-1. NOS is probably not localized in Purkinje cell, as discussed in text.

\section{climbing fiber \\ induced}

depolarization

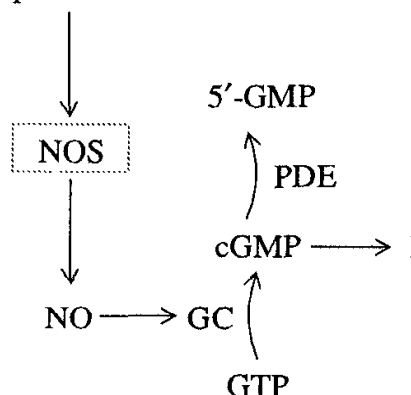

parallel fiber

induced mGluR 1

activation 
the influx of $\mathrm{Ca}^{2+}$ into the Purkinje cell from the extracellular media after climbing fiber activation was directly responsible for LTD (Ito, 1984; Linden et al., 1995), but an alternative explanation is that the $\mathrm{Ca}^{2+}$ spiking provides a means to ensure sufficient depolarization to activate nitric oxide (NO) synthase in the terminals of basket and stellate interneurons (Ito and Karachot, 1992; Linden and Conner, 1993). The axons of basket and stellate cells climh along the dendrites of Purkinje cells, often in close proximity with climbing fibers (Palay and Chan-Palay, 1974). Activation of NO synthase produces a rise in NO, which permeates the membranes of Purkinje cells. NO elevation is essential for the production of LTD and for concomitant motor learning (Crepel and Jaillard, 1990; Ito, 1991; Shibuki and Okada, 1991).

Cerebellar Purkinje cells are replete with components of the cGMP system. Purkinje cells possess abundant guanylyl cyclase (Bredt et al., 1990). Elevated NO levels stimulate guanylyl cyclase to produce cGMP from GTP (Nestler and Duman, 1994). Purkinje dendrites also contain high levels of a $\mathrm{Ca}^{2+} /$ calmodulindependent phosphodiesterase, which hydrolyzes cGMP (Nestler and Duman, 1994). High levels of cGMP-dependent protein kinase (PKG) in the brain are found only in cerebellar Purkinje cells (Nestler and Greengard, 1984). The principal substrate for PKG is G-substrate, a protein found only in Purkinje cells of the cerebellum (Nestler and Greengard, 1984).

Climbing fiber stimulation may be replaced by cGMP application in the induction of LTD (Ito and Karachot, 1992; Shibuki and Okada, 1992). Elevated cGMP levels activate PKG, which phosphorylates G-substrate. Phosphorylated G-substrate inhibits protein phosphatase-1 (PP-1) (Ito and Karachot, 1992). Application of an exogenous protein phosphatase inhibitor, such as calyculin or microcystin-LR, can also substitute for climbing fiber activation in LTD induction (Ajima and Ito, 1995). PP-1 dephosphorylates two target proteins, the AMPA receptor (Ito and Karachot, 1992), and the $\mathrm{Ca}^{2+}$-dependent potassium conductance, $g_{\mathrm{K}}$ (Reinhart and Levitan, 1995). Dephosphorylation of G-substrate is produced by calcineurin, a $\mathrm{Ca}^{2+}$-activated protein phosphatase (King et al., 1984). Phosphorylation of AMPA receptors underlies the LTD of AMPA-mediated EPSPs (Ito and Karachot, 1992). An increase in the open probahility of $\mathrm{Ca}^{2+}$-dependent $\mathrm{K}^{+}$channels in plasma membrane is produced by phosphorylation of these proteins by PKC (Baraban et al., 1985; Reinhart and Levitan, 1995 ). Thus, simultaneous activation of $P K G$ and $P K C$ will result in a persistent phosphorylation of the target proteins. Interestingly, behavioral learning in Drosophila (Griffith et al., 1994) and Hermissenda (Alkon, 1984; Nishizuka, 1986) is also dependent on phosphorylation of $\mathrm{Ca}^{2+}$-dependent $\mathrm{K}^{+}$channels.

In summary, learning in the present model is based on the hypothesis that a robust and maintained level of phosphorylation of specific target proteins is obtained by an increase in the mGluR1-mediated $\mathrm{Ca}^{2+}$ and DAG signals, coincident with an increase in cGMP through the climbing fiber pathway. Note that this assumes that substantial increases in cytoplasmic free $\mathrm{Ca}^{2+}$ in spines are not induced by climbing fiber activation under normal conditions. It is likely that spine heads are insulated from these $\mathrm{Ca}^{2+}$ increases by the activity of inhihitory interneurons (Callaway et al., 1995). Extinction of the learned response results from dephosphorylation produced by activation of the mGluR pathway alone, without a coincident climbing fiber signal. We model this learning process as follows, with a system that avoids unnecessary details of the processes depicted in Figure 6.
A climbing fiber burst produces a rapid increase in [cGMP] followed by an exponential decay. We describe this signal by a dual exponential function:

$$
[\mathrm{cGMP}]=\exp \left(-\frac{\max (0, t-s)}{\tau_{1}}\right)-\exp \left(-\frac{\max (0, t-s)}{\tau_{2}}\right),
$$

where $\tau_{1}$ and $\tau_{2}$ are the decay and rise-time constants, respectively. Each conditioning trial starts with CS onset at $t=0$. The onset of the US occurs at $t=s$.

The $\mathrm{Ca}^{2+}$-dependent activation of calcineurin involves multiple calcium/calmodulin binding sites on the regulatory subunit of the enzyme and exhibits a Hill coefficient of 3 (Burroughs et al., 1994; Stemmer and Klee, 1994). Thus, the level of activated calcineurin, $N$, is described by:

$$
\frac{d N}{d t}=k_{21}\left(N_{\max }-N\right)\left[\mathrm{Ca}^{2+}\right]_{\mathrm{cyt}}^{3}-k_{22} N
$$

Learning can now be expressed as change in $g$, the peak conductance for the $\mathrm{Ca}^{2+}$-dependent $\mathrm{K}^{+}$channel:

$$
{ }_{d t}^{d} \bar{g}=k_{23}\left(g_{\mathrm{miti}}-\bar{g}\right) C[\mathrm{cGMP}]-k_{24} N \bar{g}
$$

Because our model proposes that the learned Purkinje response topography arises primarily from the interaction between the metabotropic pathway and the $\mathrm{Ca}^{2+}$-dependent $\mathrm{K}^{+}$channel, the phosphorylation of AMPA receptors and their individual responses were omitted from the present simulations (see Discussion). We note, however, that if an equation analogous to Equation 21 governs AMPA dephosphorylation/phosphorylation, then climbing fiber-parallel fiber coincidence would produce AMPA receptor LTD and parallel fiber activity alone would produce AMPA receptor LTP, consistent with data of Sakurai (1988) and Hirano (1990).

\section{Modeling and parameter assumptions}

To simplify numerical simulation of the model, only three compartments are considered with respect to chemical concentrations at a given site: extracellular, cytosol, and lumen of the ER. Extracellular and reticular $\mathrm{Ca}^{2+}$ concentrations are assumed constant and uniform, relative to cytoplasmic concentrations. Within the cytoplasmic compartment, all points are considered to have the same concentration; that is, the temporal delays produced by diffusion are ignored. This is reasonable for the present simulations because diffusional delays in this second messenger pathway are only $10.20 \mathrm{msec}$ (Lamb and Pugh, 1992), a tiny fraction of the expected overall response time.

The CR expressed at the interpositus is influenced by a number of Purkinje cells distributed in the cortex. Thus, there are multiple $\mathrm{mGluR}$ response sites that contribute to the behavioral response. For simulation purposes, we consider 10-60 such sites, as described below. Each site was simulated by an identical set of equations (1-21) with identical parameters except for $B_{\max }$, which was varied over a range. This range of values was selected to produce responses in the observed behavioral response range of $\sim 0.1-4 \mathrm{sec}$. Although the variation in the number of mGluR receptors in cerebellar response pathways is not known, this assumption seems reasonable, because this kind of variation is seen in other cell preparations. For example, neuroblastoma cells exhibit different individual $\left[\mathrm{Ca}^{2+}\right]_{\mathrm{cyt}}$ response latencies (range, 0.4-20 sec) after carbachol application (Wang et al., 1995). Be- 
cause the carbachol concentration was always the same in these experiments, latency variation is produced by variation in the number of metabotropic receptors.

Simulations were performed on a 486-based computer, using a fourth-order Runga-Kutta algorithm with a step size in the range of 0.0005-0.002 sec. Simulations used the parameters given in Table 1. Hill coefficient, ion concentration, and dissociation constant values were taken from the literature, where possible. Other parameters were fit to published data in cases where such data were available, such as with $\mathrm{IP}_{3} \mathrm{R}$ kinetics. The results are not particularly sensitive to any given parameter value. Values near the given values produce the same qualitative results.

\section{RESULTS}

\section{Response to mGluR activation}

As shown in Figure $7 A$, activation of $\mathrm{mGluR}$ by glutamate results in a rise in intracellular calcium attributable to release from ER.

\begin{tabular}{|c|c|c|}
\hline Parameter & Value & Reason for choice \\
\hline$B_{\max }$ & Variable & See Discussion in text \\
\hline $\mathrm{k}_{1}$ & 50 & \multirow{2}{*}{$\begin{array}{l}\text { Stcady-statc from Thomsen et al. } \\
\text { (1993); assume fast reaction }\end{array}$} \\
\hline $\mathrm{k}_{2}$ & 80 & \\
\hline $\mathrm{k}_{3}$ & 0 & Assume slow enough to ignore \\
\hline $\mathrm{k}_{4}$ & 0.1 & \multirow{3}{*}{$\begin{array}{l}\text { Assume forward reaction is slow } \\
\text { (cf. Berstein et al., 1992; Casey } \\
\text { et al., 1990); total PKC inact }\end{array}$} \\
\hline $\mathrm{k}_{5}$ & 1 & \\
\hline$k_{6}$ & 20 & \\
\hline$G_{\max }$ & 1 & Arbitrary \\
\hline $\mathrm{k}_{7}$ & 4 & \multirow{3}{*}{$\begin{array}{l}\text { Chosen to produce latencies in } \\
\text { observed CR response range } \\
\text { (cf. Wang et al., 1995) }\end{array}$} \\
\hline $\mathrm{k}_{8}$ & 40 & \\
\hline$k_{9}$ & 8 & \\
\hline$I_{\max }$ & 1 & Arbitrary \\
\hline$D_{\max }$ & 1 & Arbitrary \\
\hline $\mathrm{k}_{10}$ & 5 & \multirow{2}{*}{$\begin{array}{l}K_{\mathrm{D}} \sim 6 \mu \mathrm{M} \text { (Nishizuka, 1988); rate } \\
\text { set for proper inactivation }\end{array}$} \\
\hline $\mathrm{k}_{11}$ & 30 & \\
\hline$C_{\max }^{\prime}$ & 6 & More PKC than calcineurin \\
\hline $\mathrm{k}_{12}$ & 60 & \multirow{5}{*}{$\begin{array}{l}\text { Steady-state fit to Bezprozvanny } \\
\text { et al. (1991); ratc of reactions } \\
\text { fit to fast desensitization data } \\
\text { of Levitan et al. (1993) }\end{array}$} \\
\hline $\mathrm{k}_{13}$ & 48.6 & \\
\hline $\mathbf{k}_{14}$ & 7.55 & \\
\hline $\mathbf{k}_{15}$ & 0.42 & \\
\hline$n$ & 1.65 & \\
\hline $\mathbf{k}_{16}$ & 2 & \multirow{3}{*}{$\begin{array}{l}\text { Chosen to produce a }\left[\mathrm{Ca}^{2+}\right]_{\mathrm{cyt}} \\
\text { transient of appropriate dura- } \\
\text { tion and amplitude }\end{array}$} \\
\hline $\mathbf{k}_{17}$ & 8 & \\
\hline $\mathbf{k}_{18}$ & 25 & \\
\hline $\mathrm{T}$ & $293^{\circ} \mathrm{K}$ & Eilers et al., 1995 \\
\hline$\left[\mathrm{Ca}^{2+}\right]_{\mathrm{ER}}$ & $1 \mathrm{~mm}$ & Baumann et al., 1991 \\
\hline$\left[\mathrm{Na}^{+}\right]_{\mathrm{cy} \iota}$ & $8 \mathrm{mM}$ & Eilers et al., 1995 \\
\hline$\left[\mathrm{Na}^{+}\right]_{\mathrm{ext}}$ & $125 \mathrm{~mm}$ & Eilers et al., 1995 \\
\hline$\left[\mathrm{Ca}^{2+}\right]_{\mathrm{ext}}$ & $2 \mathrm{~mm}$ & Eilers et al., 1995 \\
\hline $\mathrm{k}_{19}$ & 100 & Set amplitude of depolarizations \\
\hline $\mathrm{k}_{20}$ & 10 & Set rate of decay of potential \\
\hline$\tau_{1}$ & 0.025 & \multirow{2}{*}{$\begin{array}{l}\text { Assume [CGMP] signal has rapid } \\
\text { onset and decay }\end{array}$} \\
\hline$\tau_{2}$ & 0.005 & \\
\hline$k_{21}$ & 1 & Set amplitude and duration of $\mathrm{N}$ \\
\hline $\mathrm{k}_{22}$ & 12 & Set amplitude and duration of $\mathrm{N}$ \\
\hline$N_{\max }$ & 2 & Less calcineurin than PKC \\
\hline $\mathrm{k}_{23}$ & 2 & Set rate of learning \\
\hline$k_{24}$ & 0.4 & Set rate of extinction \\
\hline$g_{\max }$ & 600 & Need large $\bar{g}$ to hyperpolarize \\
\hline
\end{tabular}
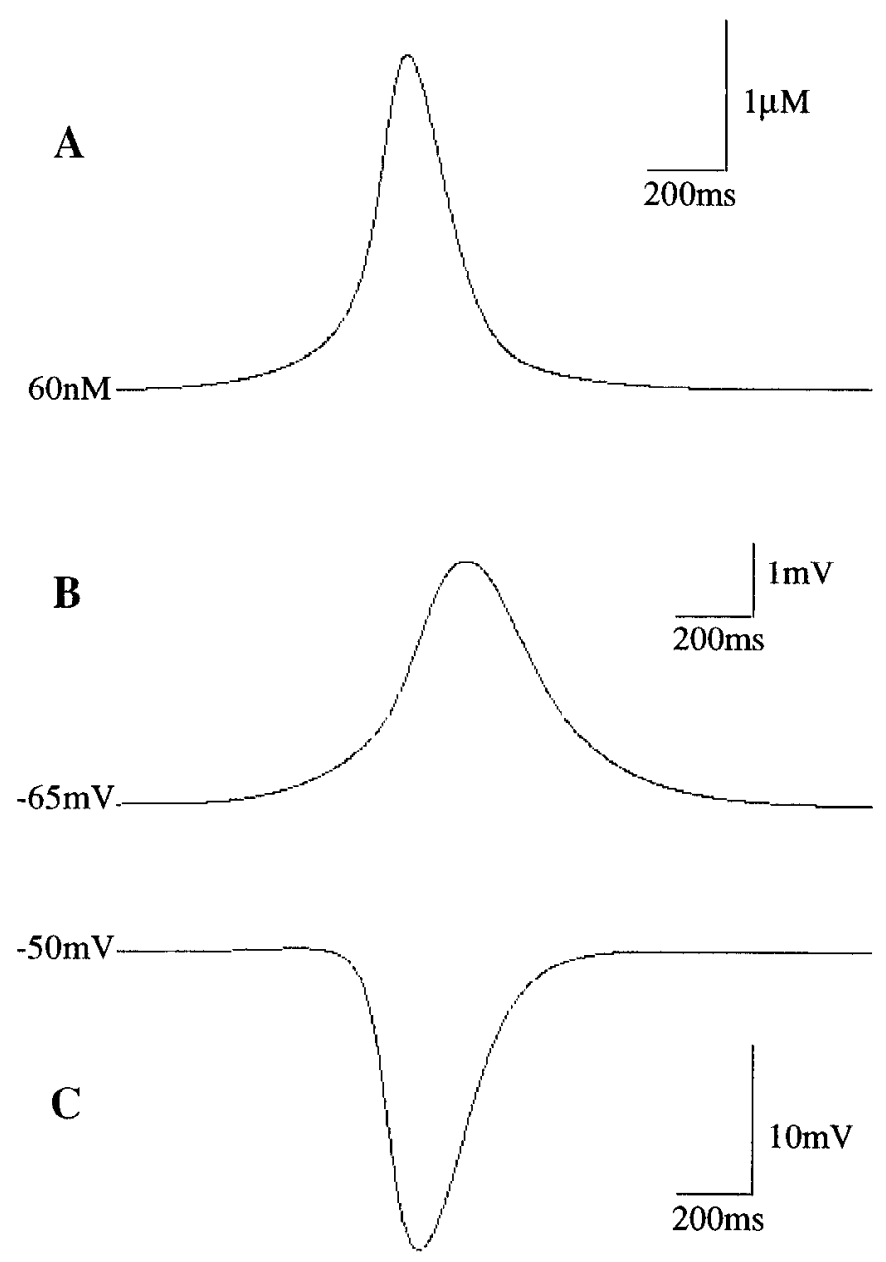

Figure 7. Model responses to mGluR activation. Parameters as described in text, with [glu] $=10 \mu \mathrm{M}, B_{\max }=1.5$. $A$, Rise in cytoplasmic calcium concentration after release from endoplasmic reticulum. $B$, The plasma membrane potential driven by the $\mathrm{Na} / \mathrm{Ca}$ exchange current in the absence of $\mathrm{Ca}^{2+}$-dependent $\mathrm{K}^{+}$current $(\bar{g}=0)$. $C$, The plasma membrane potential change when both $\mathrm{Na} / \mathrm{Ca}$ exchange current and $\mathrm{Ca}^{2+}$-dependent $\mathrm{K}^{+}$ current are present $(\bar{g}=100)$.

The calcium response builds slowly as $\mathrm{IP}_{3}$ accumulates, until the threshold for activation of positive feedback is reached. The positive feedback of calcium on $\mathrm{IP}_{3}$ production and on the $\mathrm{IP}_{3} \mathrm{R}$ channel opening results in a rapid rise in $\left[\mathrm{Ca}^{2+}\right]_{\mathrm{cyt}}$. As the calcium level increases further, the biphasic nature of the $I_{3} R$ calcium dependency (Fig. 4) switches the feedback from cxcitatory to inhibitory. Calcium release is thereby terminated. The intracellular calcium level is returned quickly to the resting level by the action of the calcium pump in ER membrane and the $\mathrm{Na} / \mathrm{Ca}$ exchanger in the plasma membrane. Because mGluR is inactivated during the calcium transient, the $\mathrm{IP}_{3}$ levels also return to baseline after the calcium transient. If the receptor continued to activate G-proteins after the initial response, intracellular calcium oscillations would develop, as observed in many preparations (Berridge et al., 1988; Devor et al., 1991).

Because the $\mathrm{Na} / \mathrm{Ca}$ exchanger is electrogenic, it will produce a depolarizing membrane current from resting potential (Fig. $7 B$ ). The membrane depolarization produced by this current may be responsible for the slow EPSPs observed in Purkinje cells after activation of mGluR at the parallel fiber-Purkinje cell synapse, as discussed below (Batchelor and Garthwaite, 1993; Batchelor et al., 1994). When the 


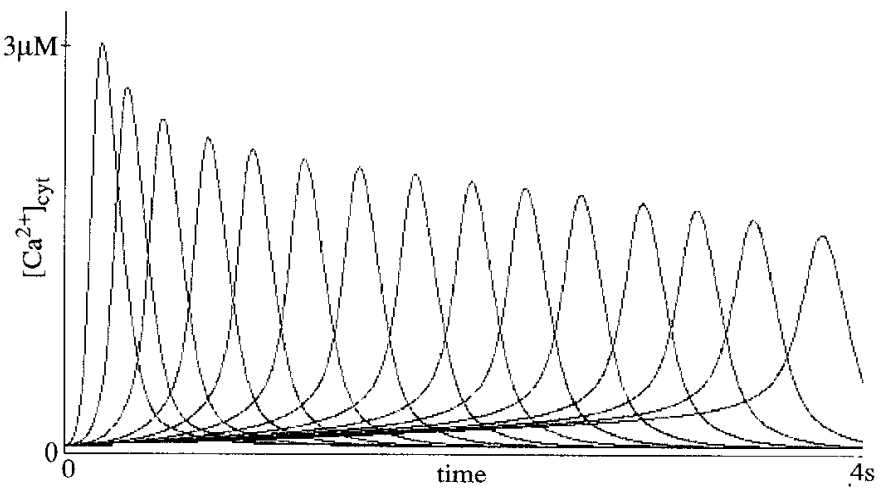

Figure 8. Spectrum produced by variation in $B_{\max }$ in response to sustained [glu] concentration. $B_{\max }=\{360,21,4.7,1.73,0.97,0.625,0.458,0.368,0.315$, $0.283,0.261,0.245,0.236,0.23,0.226\}$; these receptor concentration values were chosen to give approximately equally spaced responses spanning $4 \mathrm{sec}$. With a sustained [glu] input, $\left[\mathrm{Ca}^{2+}\right]$ spike response can be observed out to $\sim 5$ sec if the $B_{\max }$ distribution is allowed to range down to 0 .

$\mathrm{Ca}^{2+}$-dependent $\mathrm{K}^{+}$current is also activated by the intracellular calcium transient, the net effect on the membrane potential can be hyperpolarization rather than depolarization (Fig. 7C). Thus, if the input to the Purkinje cell elevates its membrane potential and establishes a certain rate of simple-spike firing, the firing rate can be decreased from this level during the calcium transient by the activation of the $\mathrm{Ca}^{2+}$-dependent $\mathrm{K}^{+}$conductance. This "pause" in Purkinje cell firing will allow an increase in activity in the interpositus cells, which govern the eye-blink response (Bullock et al., 1994). If the Purkinje cell pause is made adaptive, then a mechanism for eye-blink conditioning is realized.

\section{Population response}

Large quantities of glutamate are released presynaptically after activation. It has been estimated that the postsynaptic concentration of glutamate in the center of the synapse reaches levels $>1$ mm (Clements et al., 1992). Metabotropic receptors, however, are located at the periphery of the synapse (Nusser et al., 1994). This means that a much lower level of glutamate will reach these receptors. This concentration at the periphery will exhibit a slower decay than that in the synaptic cleft. Therefore, we assume that in response to maintained parallel fiber firing of sufficient frequency, the population of $\mathrm{mGluR}$ receptors at the synapse will be exposed to a $10 \mu \mathrm{M}$ level of glutamate.

Many of the G-protein-coupled receptor types use the second messenger system involving PLC and $\mathrm{IP}_{3}$-mediated calcium release (McGonigle and Molinoff, 1991). Responses mediated by these receptors can exhibit a wide range of temporal latencies. Serotonergic and muscarinic receptor responses can exhibit latencies of a few seconds to $>30 \mathrm{sec}$ (Berridge et al., 1988; Devor et al., 1991). The photoresponse attributable to activation of rhodopsin in the invertebrate photoreceptor has latencies on the order of tens of milliseconds (Fuortes and Hodgkin, 1964). The rapidity of the response for a given receptor type is dependent on the level of G-protein activation. This, in turn, is dependent on the level of activation of receptors. Assuming a relatively constant glutamate level of $10 \mu \mathrm{M}$, latency of the response will be dependent on the number of available receptors in the vicinity of the parallel fiber synapse.

Thus, variation in the number of mGluR1 receptors, $B_{\text {max }}$, at different synapses produces intracellular calcium responses with different latencies. Figure 8 demonstrates the effect of variation of $B_{\text {max }}$. A spectrum of calcium responses spanning the behaviorally

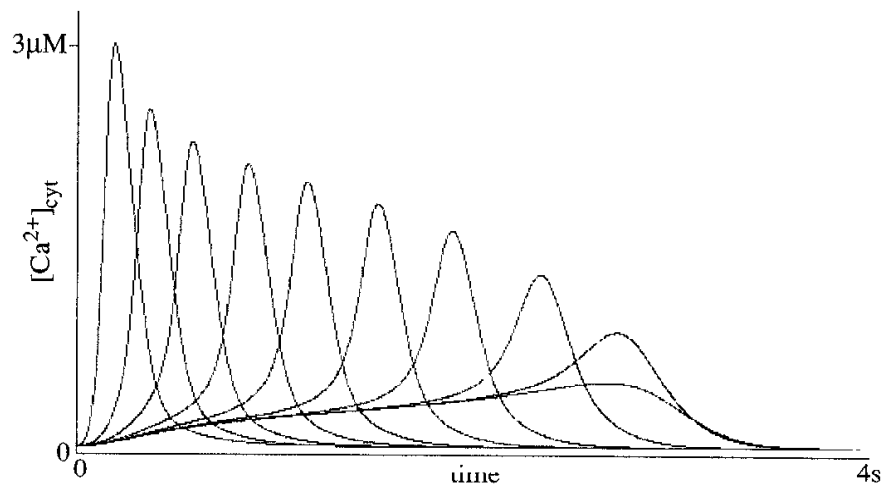

Figure 9. Spectrum produced by variation in $B_{\max }$ in response to a $50 \mathrm{msec}$ [glu] application. $B_{\max }=\{360,18,6.5,3.9,3.18,2.93,2.87,2.859,2.858$, $2.8579\}$; values within the indicated range were chosen to give equally spaced responses. The value 2.585 is the smallest $B_{\max }$ for which the $50 \mathrm{msec}$ [glu] stimulus was sufficient to induce a $\left[\mathrm{Ca}^{2+}\right]$ spike in the mGluR pathway.

relevant interval for eye blinks of $\sim 4 \mathrm{sec}$ is created in Purkinje cells by choosing $B_{\max }$ in the range of $0.1-500$. The particular values used in generating a given spectrum are given in the associated figure caption. No other parameters are varied in producing these responses. The present model is thus a biochemically derived variant of a spectral timing model (Grossberg and Schmajuk, 1989; Grossberg and Merrill, 1992; Bullock et al., 1994). The spectrum of response times can be used to learn an adaptively timed eye blink, as discussed below.

Although for purposes of simulation we assumed that the latency variations are attributable wholly to a natural spectrum of $B_{\text {max }}$ values, it is possible that variance in other mGluR pathway components may contribute to generation of different latencies. For example, variations in $\mathrm{IP}_{3} \mathrm{R}$ density or in luminal calcium stores, which affect the rate of mGluR-mediated $\mathrm{Ca}^{2+}$ release, will affect response latency.

The model exhibits different calcium response properties to transient versus maintained agonist concentrations. Although maintained parallel fiber inputs produce a spectrum that spans 4 $\mathrm{sec}$, a transient parallel fiber activation of $50 \mathrm{msec}$ duration admits only a spectrum spanning $\sim 2 \mathrm{sec}$. This is because the dynamics engendered by a $50 \mathrm{msec}$ stimulus fail to generate a $\left[\mathrm{Ca}^{2+}\right]$ spike in mGluR pathways whose $B_{\text {max }}$ values are associated with longer latencies. Figure 9 shows the spectral response properties of the model to $50 \mathrm{msec}$ parallel fiber activations. This difference in the spectral properties of transient versus maintained inputs is analogous to the differences in the maximal ISIs for trace versus delay eye-blink conditioning (Smith et al., 1969; Solomon et al., 1986).

Measurement of the potential of a population of Purkinje cells in slicc reveals a slow response after brief activation of parallel fibers (Batchelor and Garthwaite, 1993; Batchelor et al., 1994). The response has a slow rise-time, with a peak at 300-700 msec and a slow decay over several seconds (Fig. 10A). The response is observable in a bath of ionotropic glutamate and GABA antagonists, which suggests that the response is mediated by mGluRs at the parallel fiber-Purkinje cell synapses. This type of response is the result of the summation of the individual signals in a spectrum, such as that of Figure 8 or 9 . Figure $10 B$ shows the summation of the potential changes produced by $\mathrm{Na} / \mathrm{Ca}$ exchange current in a heterogeneous population of $\mathrm{mGluR}$ response pathways. This 


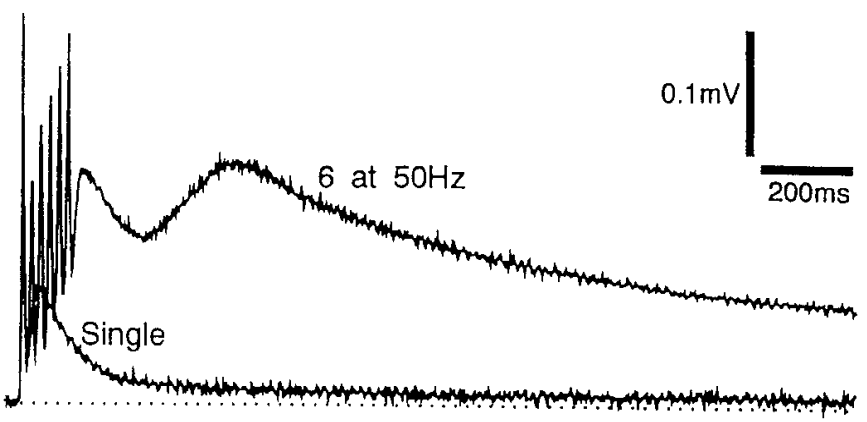

A

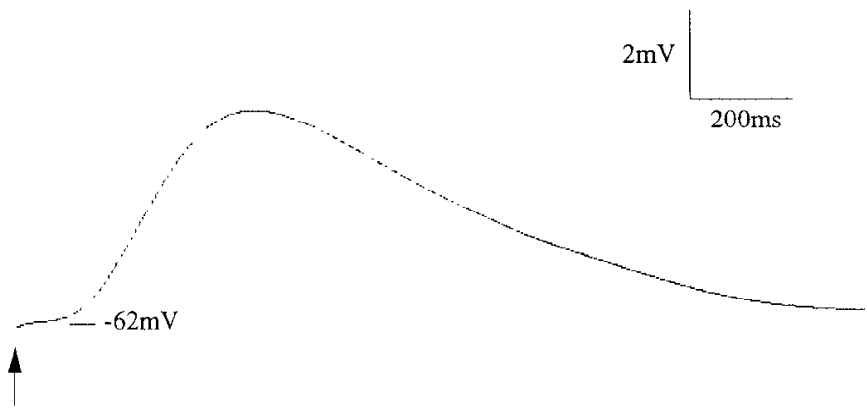

B

Figure 10. A, Metabotropic glutamate response in a slice population of Purkinje cells recorded using the three-chamber grease-gap method. (Reprinted with permission from Batchelor and Garthwaitc, 1993.) B, Model population response produced by summation of spectral components in response to a $150 \mathrm{msec}$ agonist application at the arrow, with $\alpha=0.1$, $N=60, B_{\max }=\{360,170,100,65,42,29,21,15.7,12,9.2,7.2,5.8,4.7,3.8$, $3.15,2.65,2.25,1.96,1.73,1.55,1.4,1.27,1.15,1.06,0.97,0.89,0.82,0.763$, $0.706,0.66,0.625,0.59,0.555,0.525,0.5,0.478,0.458,0.44,0.422,0.407$, $0.393,0.38,0.368,0.357,0.347,0.338,0.33,0.322,0.315,0.309,0.303,0.298$, $0.293,0.288,0.283,0.279,0.275,0.271,0.267,0.264\}$; values within the indicated range were chosen to give a smooth population response. This distribution was used for all results except those reported in Figures 8 and 9.

population signal, $P(t)$, is computed by:

$$
P(t)=\alpha \sum_{i=1}^{N} \Delta V_{i}+V_{b},
$$

where $N$ is number of response pathways, $\Delta V_{\mathrm{i}}=\left(V_{\mathrm{i}}-V_{\mathrm{b}}\right)$ is the mGluR-induced potential change in a given pathway, $\alpha$ is a constant scaling factor, and $V_{\mathrm{b}}$ is the baseline resting potential of the population.

As shown in Figure 10, even though the individual responses are localized in time, the population signal is broad and smooth bccausc of distribution of the localized signals throughout a long interval. This population response phenomenon also is seen in other $\mathrm{IP}_{3}$-mediated response systems, such as histamine receptors of HeLa cells (Bootman, 1994).

\section{Conditioning}

Given a CS-activated spectrum of responses distributed among a population of response pathways, a US input can select spectral components that will produce the desired behavioral response (Grossberg and Schmajuk, 1989). In the present model, the CS is parallel fiber activation of mGluRs, whereas the climbing fibers produce the [cGMP] increase at US onset. Figure 11 shows the population response during 36 pairings of a $600 \mathrm{msec} C S$ and a $100 \mathrm{msec}$ US. The CS and US coterminate, such that the ISI is 500

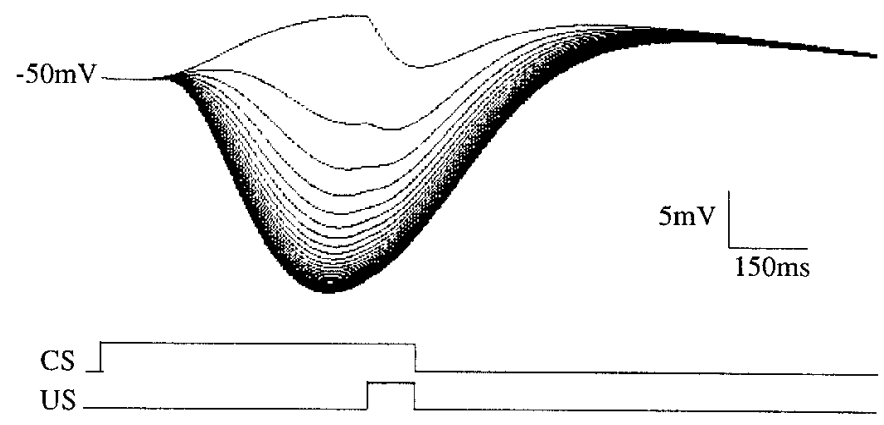

Figure 11. Progress of model population response during 30 pairings of CS and US at an ISI of $500 \mathrm{msec}$. Initially, mGluR activation produces a depolarizing response, but as learning progresses, a timed hyperpolarization is realized. Spectral components are the same as for Figure $10 B$.

msec. Note that the rate of learning is accelerated from that observed in experiments to decrease simulation time. Also, learning is asymptotic because of the balance between CS-driven dephosphorylation and CS- and US-driven phosphorylation. CSdriven dephosphorylation alone causes extinction of the learned response.

Those mGluR response pathways that have PKC activity at the time of climbing fiber activation correlated with US onset exhibit a persistent phosphorylation of $\mathrm{Ca}^{2+}$-dependent $\mathrm{K}^{+}$channels. This increases the peak conductance of these channels in response to the intracellular calcium transient, such that these pathways produce a more hyperpolarizing response after repeated pairings. Thus, those Purkinje cells whose CS-activated mGluR1 pathway has a latency that approximates the ISI will exhibit a progressive decrease in simple-spike firing during the CS-US interval. Other Purkinje cells will exhibit increases in simple-spike firing in the CS-US interval attributable to the depolarizing $\mathrm{Na} / \mathrm{CA}$ exchanger as well as the AMPA receptor input. Those cells exhibiting a decrease in firing will realize a minimum firing rate near the expected time of US onset. These characteristics are in agreement with in vivo recordings of Purkinje cell activity during eye-blink conditioning (Berthier and Moore, 1986; Thompson, 1990).

Interpositus nuclear cells receive input from a population of Purkinje cclls. Thereforc, the population response shown in Figure 11 is responsible for the observed CR-related activity in interpositus. In agreement with recordings from interpositus (Fig. 12), the population response peak occurs before the time of the expected US. Both the latency of the response peak and the response onset latency decrease during learning.

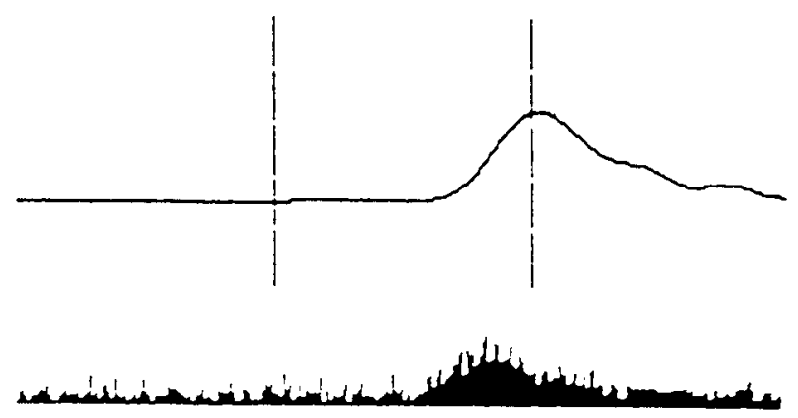

Figure 12. Average nictitating membrane movement (top) and peristimulus histogram of interpositus nucleus neural activity (bottom) during classical conditioning of a rabbit with a $25 \mathrm{msec}$ pontine stimulation as the CS and an air-puff delivered $225 \mathrm{msec}$ later as the US. (Reprinted with permission from Steinmetz, 1990b.) 


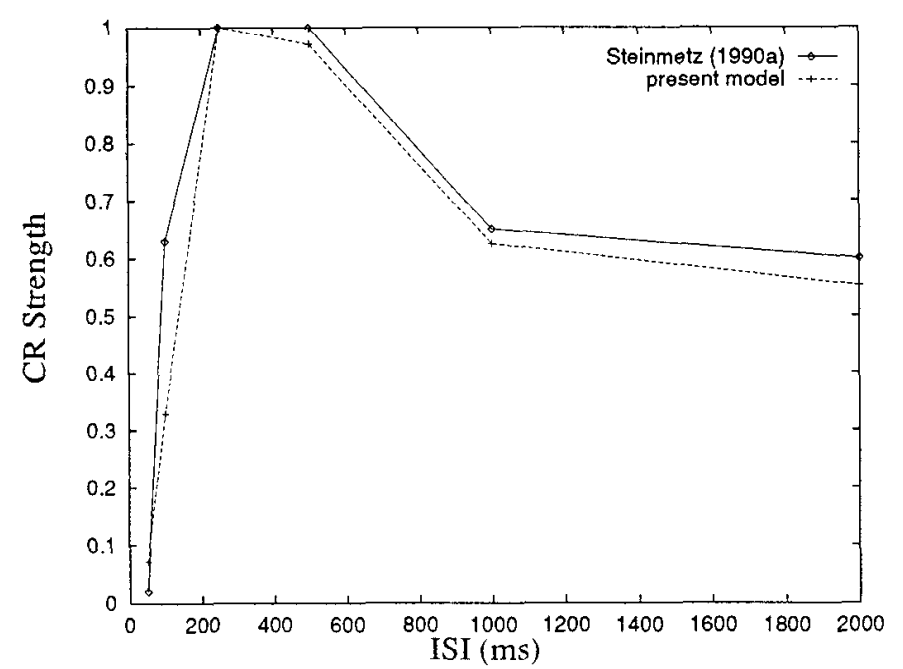

Figure 13. Comparison of CR strength-ISI dependency curves for the model and the behavioral data. Data of Steinmetz (1990a) is normalized to $86 \%$ CRs. Model data are the magnitude of the learned hyperpolarization below $-50 \mathrm{mV}$, normalized to the amount of hyperpolarization obtained at asymptote during training with an ISI of $250 \mathrm{mscc}$.

The strength of the CR depends on ISI in a characteristic way. CR strength is maximal at ISIs of $200-400 \mathrm{msec}$ and is reduced at shorter or longer ISls (Smith et al., 1969; Steinmetz, 1990a). By taking the depth of the population response as a measure of CR strength, it is possible to reconstruct the CR strength-ISI dependency curve produced by the model. Figure 13 shows the curve for the model in comparison with the experimental data obtained by Steinmetz (1990a). Strength of CR in the experiment is calculated as percentage CRs over test trials. For the model, CR strength is calculated by the magnitude of hyperpolarization below the baseline value of $-50 \mathrm{mV}$. As shown in the figure, the model reproduces the characteristic ISI dependency as measured behaviorally.

A spectral timing model is able to produce double-responding after conditioning with two different ISIs in alternation. Figure 14 depicts the effect of conditioning with alternating ISIs of $350 \mathrm{msec}$ and $1000 \mathrm{msec}$. A double-peaked CR is produced with peaks near the expected times of the US, and with the Weber law property (compare Fig. 2) whereby the earlier peak is narrower and the later peak broader. The figure also demonstrates extinction of a learned response with repeated presentation of the CS alone.
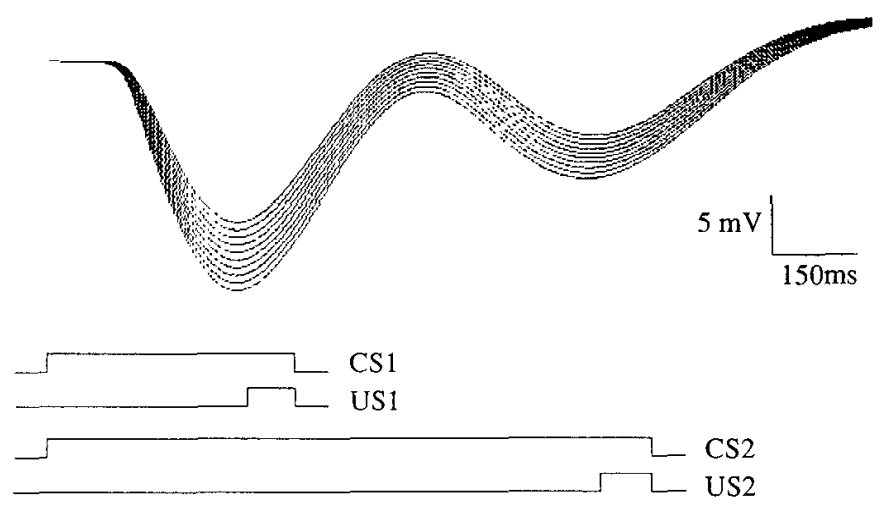

Figure 14. Progress of population response during first 10 extinction trials after 30 CS-US pairings with alternating ISIs of 350 and 1000 msec. After conditioning, the $1100 \mathrm{msec}$ CS2 is used to elicit a doublepeaked CR.
Two sites of learning need to be considered in eye-blink conditioning: cerebellar cortex and interpositus. Although the present model focuses on learning in cortex, the result is compatible with an additional learning site in the interpositus (Fig. 1). Learning at mossy fiber synapses on nuclear cells can provide a learned gain that can be expressed through the interpositus when Purkinje cell activity pauses. In this way, learning at Purkinje cells opens a timed gate that enables learned gains at the intracerebellar nuclei to control a movement at the appropriate time. We have demonstrated previously that the existence of this type of interpositus learning in conjunction with cortical learning can explain the maladaptively timed CRs, which can occur after cortical lesions (Bullock et al., 1994).

\section{DISCUSSION}

As described in the introduction, the most parsimonious explanation for direct mossy fiber stimulation producing a timed response in interpositus is that a timing function is present in the cerebellum. The present model demonstrates that the mGluR1phosphoinositide hydrolysis second messenger system in cerebellar Purkinje cells can perform a timing function, both in maintaining a CS trace for association with a temporally remote US and in the delayed onset of the CR.

The basic scheme of Figure 6 for control of phosphorylation has been recognized for many years (Nestler and Greengard, 1984, their Fig. 9.3). It is important to realize, however, that the cGMP signal that increases levels of phosphorylation is antagonized by the parallel fiber-mediated intracellular calcium signal, which decreases phosphorylation. The fact that the cGMP signal corresponds to a US signal, whereas the mGluR activation corresponds to a CS signal, makes it clear that conditioning is obtainable only when activation of these pathways occurs in temporal conjunction. Activation of the mGluR pathway alone gradually reverses the effects of any previous conjunctive activation.

\section{LTD of AMPA receptors}

Although the phosphorylation of AMPA receptors is nol crucial to behavioral learning in the model, it certainly has some bearing in vivo. The exact role played by the AMPA receptor in eye-blink conditioning remains an unresolved issue. It is not even clear whether AMPA receptor activation is necessary for AMPA receptor LTD (Linden et al., 1993). Nonetheless, it seems that the mechanisms inducing AMPA receptor LTD are also responsible for behavioral learning, possibly through the phosphorylation of $\mathrm{Ca}^{2+}$-dependent $\mathrm{K}^{+}$channels. The fact that $\mathrm{mGluR} 1$ is critical for induction of AMPA receptor LTD (Aiba et al., 1994; Shigemoto et al., 1994) motivates our hypothesis that it is temporal correlation of the mGluR1-mediated second messengers and the climbing fiber-evoked cGMP signal that produce behavioral learning.

Aiba et al. (1994) reported loss of AMPA receptor LTD and diminished but extant eye-blink conditioning in mice lacking mGluR1. Furthermore, the eye blink seems to be timed correctly, although a detailed study over various ISIs was not conducted. This would seem to argue that mGluR1 is not involved in timing; however, another possible explanation for this finding is that mGluR5, which also couples to phosphoinositide hydrolysis, is able to partially replace mGluR1 functionally in the mutant mice. The mGluR5 subtype is present in Purkinje cells of immature rat brain (Abe et al., 1992), but during development is normally supplanted by a proliferation of mGluR1 (Shigemoto et al., 1992). To completely rule out a role for mGluR-mediated phosphoino- 
sitide hydrolysis in timing, both subtypes would need to be eliminated.

A recent report by Linden et al. (1995) demonstrates that activation of the NO/cGMP pathway is not required for LTD in culture. It suffices to depolarize Purkinje cells $(3 \mathrm{sec}$ of $+10 \mathrm{mV})$ significantly in conjunction witl application of glutamate. Kasono and Hirano (1994) found that the depolarization can be replaced by an artificial elevation of intracellular calcium to $6 \mu \mathrm{M}$ in LTD induction. Linden et al. (1995) reported that the LTD they observed is blocked by PKC inhibitors but not inhibitors of PKG. According to the model of Figure 6, a large enough $\left[\mathrm{Ca}^{2+}\right]_{c y t}$ rise can evoke LTD in the absence of cGMP. This is attributable to the fact that calcium activates PLC, which produces DAG. The combination of high levels of calcium and DAG could drive PKC phosphorylation beyond that recoverable by baseline protein phosphatase activity. This can be realized in Equation 21 by assuming nonzero resting levels of cGMP. Our hypothesis, however, is that this situation is not occurring in vivo. Both mGluR1activated PKC and climbing fiber-activated PKG must be present for LTD.

A possible role for AMPA receptor LTD could be to unblock the mGluR-mediated response, which is inhibited by AMPA receptor stimulation (Lonart et al., 1993). The mechanism studied by Lonart et al. (1993) seems to involve AMPA activation of voltage-dependent calcium channels and subsequent activation of a calcium-dependent protein kinase. In the present model, significant calcium influx would result in activation of calciumdependent PLC and thus would invariably stimulate, rather than inhibit, formation of $\mathrm{IP}_{3}$. Therefore, LTD does not seem to unblock mGluR responses in the Purkinje cell. The manner of interaction between $\mathrm{mGluR}$ and AMPA receptors in cerebellar Purkinje cells awaits further investigation.

\section{Purkinje cell and invertebrate photoreceptor}

The biochemistry of the invertebrate photoresponse is similar to the biochemistry of the Purkinje cell mGluR response. In the invertebrate photoreceptor light activates rhodopsin. Activated rhodopsin stimulates PLC through a G-protein (Yarfic and Hurley, 1994), as described above for mGluR. In both invertebrate photoreceptors and Purkinje cells, activated PLC catalyzes the production of the second-messengers $\mathrm{IP}_{3}$ and DAG from $\mathrm{PIP}_{2}$, and $\mathrm{IP}_{3}$ subsequently releases calcium from intracellular stores. The rapid increase of the cytosolic calcium concentration in the invertebrate photoreceptor activates a plasma membrane $\mathrm{Na}^{+}$ conductance, which produces a depolarizing photoresponse (Shin et al., 1993). The specific mechanisms that activate this conductance in the invertebrate photoreceptor are not well understood, but they may involve $\mathrm{Ca}^{2+}$-stimulated increases in cGMP (Bacigalupo et al., 1991; Richard et al., 1995).

The photoreceptor is a site of associative conditioning in marine mollusks such as Hermissenda (Alkon, 1984; Crow, 1988). Repeated pairings of light and rotation with a forward ISI results in a persistent suppression of photokinesis in these animals (Matzel el al., 1990). This behavioral change is affected by a modification of voltage-dependent and $\mathrm{Ca}^{2+}$-dependent $\mathrm{K}^{+}$conductances within the photoreceptor (Alkon, 1986). Similarly, the Purkinje cell seems to play an essential role in certain forms of classical conditioning. Our theory proposes that, like the invertebrate photoreceptor, behavioral learning in the cerebellum can be produced by persistent modification of a $\mathrm{Ca}^{2+}$-dependent $\mathrm{K}^{+}$ conductance.

The biochemical cascade producing the invertebrate photore- sponse is designed to remain sensitive to light over a wide range of stimulus intensities and durations. Weak signals are amplified and prolonged by the positive feedback in the biochemical cascade. This amplification results in a single absorbed photon opening 1000 plasma membrane channels and eliciting a current transient of several nanoamps in Limulus ventral photoreceptors (Nagy, 1991). The photocurrent in response to a maintained stimulus is reduced through negative feedback in the second messenger pathway, ensuring that a transient photoresponse can be produced even at high background intensities (Fuortes and Hodgkin, 1964). A similar mechanism seems to occur in turtle cones (Baylor and Hodgkin, 1974) and has been modeled by a $\mathrm{Ca}^{2+}$-mediated gating function (Carpenter and Grossberg, 1981).

Our theory suggests that the Purkinje cell uses something very similar to the robust signal transduction mechanism of photoreception for the specialized purpose of forming associations between temporally separated stimuli. In both cases, there is a functional need to respond reliably to signals whose intensity and duration may vary over a wide range. In the photoreceptor, this variation is attributable to changes in photon density. In the cerebellar cortex, it is attributable to variations in the number of convergent CS-activated cells. The mechanisms in question may have evolved to improve the signal-to-noise ratio in response to weak signals by amplifying and prolonging them without losing sensitivity or temporal resolution to more intense signals. Whether this relationship between Purkinje cell and invertebrate photoreceptor represents convergent evolution or a true homology is an open question. Homology is possible because associative learning arises in the invertebrates and probably postdates the evolution of photoreceptors, whereas cerebellar and Purkinje cells are not found until the vertebrates, for which the cerebellum is virtually a defining feature. Data on protochordates may be able to shed light on this question.

Another link warranting exploration is with the dentate-CA3 circuit in hippocampus, which exhibits adaptive timing (Hochler and Thompson, 1980; Berger et al., 1986) and seems to use mechanisms on the circuit level that are similar in many respects to those used here. Grossberg and Merrill (in press) have discussed how the hippocampal circuit may fit into a larger model neural architecture for timed reinforcement learning, attention, and movement control through interactions between the hippocampal system and cerebellum, among other brain regions. Taken together, these functional similarities suggest that learned timing in the cerebellum uses a specialized version of neural mechanisms that are of much broader occurrence and functional significance.

\section{REFERENCES}

Abe T, Sugihara H, Nawa H, Shigemoto R, Mizuno N, Nakanishi S (1992) Molecular characterization of a novel metabotropic glutamate receptor mGLUR5 coupled to inositol phosphate $/ \mathrm{Ca}^{2+}$ signal transduction. J Biol Chem 267:13361-13368.

Aiba A, Kano M, Chen C, Stanton ME, Fox GD, Herrup K, Zwingman TA, Tonegawa S (1994) Deficient cerebellar long-term depression and impaired motor learning in mGluR1 mutant mice. Cell 79:377-388.

Ajima A, Ito M (1995) A unique role of protein phosphatases in cercbellar long-term depression. NeuroReport 6:297-300.

Alkon DL (1984) Calcium-mediated reduction of ionic currents: a biophysical memory trace. Science 226:1037-1045.

Alkon DL (1986) Changes of membrane currents and calciumdependent phosphorylation during associative conditioning. In: Neural mechanisms of conditioning (Alkon DL, Woody CD, eds), pp. 3-18. New York: Plenum. 
Bacigalupo J, Johnson EC, Vergara C, Lisman JE (1991) Cyclic GMP opens light-dependent channels in excised patches of Limulus ventral photoreceptors (Abstr). Biophys J 59:530A.

Baraban JM, Snyder SH, Alger BE (1985) Protein kinase C regulates ionic conductance in hippocampal pyramidal neurons: electrophysiological effects of phorbol esters. Proc Natl Acad Sci USA 82:2538-2542.

Bartha GT, Thompson RF (1992a) Control of rabbit nictitating membrane movements. I. A computer model of the retractor bulbi muscle and the associated orbital mechanics. Biol Cybern 68:135-143.

Bartha GT, Thompson RF (1992b) Control of rabbit nictitating membrane movements. II. Analysis of the relation of motoneuron activity to behavior. Biol Cybern 68:145-154.

Bartha GT, Thompson RF, Gluck MA (1991) Sensorimotor learning and the cerebellum. In: Visual structures and integrated functions (Arbib M, Ewert J, eds), pp 381-396. Berlin: Springer.

Batchelor AM, Garthwaite J (1993) Novel synaptic potentials in cerebellar Purkinje cells: probable mediation by metabotropic glutamate receptors. Neuropharmacology 32:11-20.

Batchelor AM, Madge DJ, Garthwaite J (1994) Synaptic activation of metabotropic glutamate receptors in the parallel fiber-Purkinje cell pathway in rat cerebellar slices. Neuroscience 63:911-915.

Baumann O, Walz B, Somlyo AV, Somlyo AP (1991) Electron probe microanalysis of calcium release and magnesium uptake by endoplasmic reticulum in bee photoreceptors. Proc Natl Acad Sci USA 88:741-744.

Baylor DA, Hodgkin AL (1974) Changes in time scale and sensitivity in turtle photoreceptors. J Physiol (Lond) 242:729-758.

Berger TW, Berry SD, Thompson RF (1986) Role of the hippocampus in classical conditioning of aversive and appetitive behaviors. In: The hippocampus, Vol 4 (Isaacson RL, Pribram KH, eds), pp 203-239. New York: Plenum.

Berstein G, Blanks JL, Smrcka AV, Higashijima T, Sternweis PC, Exton JH, Ross EM (1992) Reconstitution of agonist-stimulated phosphatidylinositol 4,5-bisphosphate hydrolysis using purified $\mathrm{m} 1$ muscarinic receptor, $\mathbf{G}_{\mathrm{q}^{\prime} 11}$, and phospholipase C- $\beta 1$. J Biol Chem 267:8081-8088.

Berridge MJ, Cobbold PH, Cuthbertson KSR (1988) Spatial and temporal aspects of cell signalling. Philos Trans R Soc Lond [Biol] 320:325-343.

Berthier NE, Moore JW (1986) Cerebellar Purkinje cell activity related to the classically conditioned nictitating membrane response. Brain Res 63:341-350.

Bezprozvanny I, Watras J, Ehrlich BE (1991) Bell-shaped calciumresponse curves of $\operatorname{Ins}(1,4,5) \mathrm{P}_{3^{-}}$and calcium-gated channels from endoplasmic reticulum of cerebellum. Nature 351:751-754.

Bielefeldt K, Jackson MB (1994) Phosphorylation and dephosphorylation modulate a $\mathrm{Ca}^{2+}$-activated $\mathrm{K}^{+}$channel in rat peptidergic nerve terminals. J Physiol (Lond) 475.2:241-254.

Blackstone CD, Supattapone S, Snyder SH (1989) Inositolphospholipidlinked glutamate receptors mediate cerebellar parallel fiber-Purkinje cell synaptic transmission. Proc Natl Acad Sci USA 86:4316-4320.

Bootman MD (1994) Quantal $\mathrm{Ca}^{2+}$ release from Ins P3-sensitive intracellular $\mathrm{Ca}^{2+}$ stores. Mol Cell Endocrinol 98:157-166.

Bredt DS, Hwang PM, Snyder SH (1990) Localization of nitric oxide synthase indicating a neural role for nitric oxide. Nature 347:768-770.

Bullock D, Fiala JC, Grossberg S (1994) A neural model of timed response learning in the cerebellum. Neural Networks 7:1101-1114.

Buonomano DV, Mauk MD (1994) Neural network model of the cerebellum: temporal discrimination and the timing of motor responses. Neural Comput 6:38-55.

Burroughs SE, Horrocks WD, Ren H, Klee CB (1994) Characterization of the lanthanide ion-binding properties of calcineurin- $B$ using laserinduced luminescence spectroscopy. Biochemistry 33:10428-10436.

Callaway JC, Lasser-Ross N, Ross WN (1995) IPSPs strongly inhibit climbing fiber-activated $\left[\mathrm{Ca}^{2+}\right]$ increases in the dendrites of cerebellar Purkinje neurons. I Neurosci 15:2777-2787.

Carafoli E (1987) Intracellular calcium homeostasis. Annu Rev Biochem 56:395-433.

Carpenter GA, Grossberg S (1981) Adaptation and transmitter gating in vertebrate photorcceptors. J Theor Neurobiol 1:1-42.

Casey PJ, Fong HKW, Simon MI, Gilman AG (1990) $\mathrm{G}_{z}$, a guanine nucleotide-binding protein with unique biochemical properties. J Biol Chem 265:2383-2390.

Catania MV, Aronica E, Sortino MA, Canonico PL, Nicoletti F (1991) Desensitization of metabotropic glutamate receptors in neuronal cultures. J Neurochem 56:1329-1335.
Chapeau-Blondeau F, Chauvet G (1991) A neural network model of the cerebellar cortex performing dynamic associations. Biol Cybern 65:267-279.

Chen SRW, MacLennan DH (1994) Identification of calmodulin-, $\mathrm{Ca}^{2+}$, and ruthenium red-binding domains in the $\mathrm{Ca}^{2+}$ release channel (ryanodine receptor) of rabbit skeletal muscle sarcoplasmic reticulum. J Biol Chem 269:22698-22704.

Chen SR, Zhang L, MacLennan DH (1992) Characterization of a $\mathrm{Ca}^{2+}$ binding and regulatory site in the $\mathrm{Ca}^{2+}$ release channel (ryanodine receptor) of rabbit skeletal muscle sarcoplasmic reticulum. J Biol Chem 267:23318-23326.

Clements JD, Lester RAJ, Tong G, Jahr CE, Westbrook GL (1992) The time course of glutamate in the synaptic cleft. Science 258:1496-1501.

Coleman SR, Gormezano I (1971) Classical conditioning of the rabbit's (Oryctolagus cuniculus) nictitating membrane response under symmetrical CS-US interval shifts. J Comp Physiol Psychol 77:447-455.

Crepel F, Jaillard D (1990) Protein kinases, nitric oxide and long-term depression of synapses in the cerebellum. NeuroReport 1:133-136.

Crow T (1988) Cellular and molecular analysis of associative learning and memory in Hermissenda. Trends Neurosci 11:136-112.

Daniel H, Hemart N, Jaillard D, Crepel F (1992) Coactivation of metabotropic glutamate receptors and of voltage-gated calcium channels induces long-term depression in cerebellar Purkinje cells in vitro. Exp Brain Res 90:327-331.

De Mcis L, Incsi G (1982) The transport of calciun by sacroplasmic reticulum and various microsomal preparations. In: Membrane transport of calcium (Carafoli E, ed), pp 141-186. London: Academic.

De Schutter E, Bower JM (1994a) An active membrane model of the cerebellar Purkinje cell. I. Simulation of current clamps in slicc. J Neurophysiol 71:375-400.

De Schutter E, Bower JM (1994b) An aclive membrane model of the cerebellar Purkinje cell. II. Simulation of synaptic responses. J Neurophysiol 71:401-419.

Devor DC, Ahmed Z, Duffey ME (1991) Cholinergic stimulation produces oscillations of cytosolic $\mathrm{Ca}^{2+}$ in a secretory epithelial cell line, T84. Am J Physiol 260:C598-608.

Eilers J, Augustine GJ, Konnerth A (1995) Subthreshold synaptic $\mathrm{Ca}^{2+}$ signalling in fine dendrites and spines of cerebellar Purkinje neurons. Nature 373:155-158.

Fagni L, Bossu JL, Bockaert J (1991) Activation of a large-conductance $\mathrm{Ca}^{2+}$-dependent $\mathrm{K}^{+}$channel by stimulation of glutamate phosphoinositide-coupled receptors in cultured cerebellar granule cells. Eur J Neurosci 3:778-789.

Freeman JA (1969) The cerebellum as a timing device: an experimental study in the frog. In: Neurobiology of cerebellar evolution and development (Llinás R, ed), pp 397-420. Chicago: American Medical Association.

Fuortes MGF, Hodgkin AL (1964) Changes in time scale and sensitivity in the ommatidia of Limulus. J Physiol (Lond) 172:239-263.

Furuichi T, Mikoshiba K (1995) Inositol 1,4,5-trisphosphate receptormediated $\mathrm{Ca}^{2+}$ signaling in the brain. J Neurochem 64:953-960.

Glaum SR, Slater NT, Rossi DJ, Miller RJ (1992) Role of metabotropic glutamate (ACPD) receptors at the parallel fiber-Purkinje cell synapse. J Neurophysiol 68:1453-1462.

Gormezano I (1966) Classical conditioning. In: Expcrimental methods and instrumentation in psychology (Sidowski JB, ed), pp 385-420. New York: McGraw-Hill.

Griffitlı LC, Wang J, Zhong Y, Wu C-F, Greenspan RJ (1994) Calcium/ calmodulin-dependent protein kinase II and potassium channel subunit Eag similarly affect plasticity in Drosophila. Proc Natl Acad Sci USA 91:10044-10048.

Grossberg S, Merrill JWL (1992) A neural network model of adaptively timed reinforcement learning and hippocampal dynamics. Cognit Brain Res 1:3-38.

Grossberg S, Merrill JWL (1996) The hippocampus and cerebellum in adaptively timed learning, recognition, and movement. J Cognit Neurosci, in press.

Grossberg S, Schmajuk NA (1989) Neural dynamics of adaptive timing and temporal discrimination during associative learning. Neural Networks 2:79-102.

Hartell NA (1994) Induction of cerebellar long-term depression requires activation of glutamate metabotropic receptors. NeuroReport 5:913-916. 
Herrero I, Miras-Portugal MT, Sanchez-Prieto J (1994) Rapid desensitization of the metabotropic glutamate receptor that facilitate glutamate release in rat cerebrocortical nerve terminals. Eur J Neurosci 6:115-120.

Hirano T (1990) Depression and potentiation of the synaptic transmission between a granule cell and a Purkinje cell in rat cerebellar culture. Neurosci Lett 119:141-144.

Hodgkin AL, Nunn BJ (1987) The effect of ions on sodium-calcium exchange in salamander rods. J Physiol (Lond) 391:371-398.

Hoehler FK, Leonard DW (1976) Double responding in classical nictitating membrane conditioning with single-CS dual-ISI training. Pavlov $\mathbf{J}$ Biol Sci 11:180-190.

Hoehler FK, Thompson RF (1980) Effects of the interstimulus (CSUCS) interval on hippocampal unit activity during classical conditioning of the nictitating membrane response of the rabbit (Oryctolagus cuniculus). J Comp Pliysiol Psychol 94:201-215.

Homma Y, Imaki J, Nakanishi O, Takenawa T (1988) Isolation of characterization of two different forms of inositol phospholipid-specific phospholipase C from rat brain. J Biol Chem 263:6592-6598.

Iino M (1990) Biphasic $\mathrm{Ca}^{2+}$ dependence of inositol 1,4,5-trisphosphateinduced Ca release in smooth muscle cells of the guinea pig Taenia caeci. J Gen Physiol 95:1103-1122.

Ito M (1984) The cerebellum and neural control. New York: Raven.

Ito M (1991) The cellular basis of ccrebcllar plasticity. Curr Opin Ncurobiol 1:616-620.

Ito M, Karachot L (1992) Protein kinases and phosphatase inhibitors mediating long-term desensitization of glutamate receptors in cerebellar Purkinje cells. Ncurosci Res 14:27-38.

Jaffe S (1992) A neuronal model for variable latency response. In: Analysis and modeling of neural systems (Eeckman FH, ed), pp 405-410. Boston: Kluwer Academic Publishers.

Joseph SK, Rice HL, Williamson JR (1989) The effect of external calcium and $\mathrm{pH}$ on inositol trisphosphate-mediated calcium release from cerebellum microsomal fractions. Biochem J 258:261-265.

Kasono K, Hirano T (1994) Critical role of postsynaptic calcium in cerebellar long-term depression. NeuroReport 6:17-20.

Kasono K, Hirano T (1995) Involvement of inositol trisphosphate in ccrebellar long-term depression. NeuroReport 6:569-572.

Khodakhah K, Ogden D (1993) Functional heterogeneity of calcium release by inositol trisphosphate in single Purkinje neurones, cultured cerebellar astrocytes, and peripheral tissues. Proc Natl Acad Sci USA 90:4976-4980.

King MM, Huang CY, Chock PB, Nairn AC, Hemmings Jr HC, Chan K-FJ, Greengard P (1984) Mammalian brain phosphoproteins as substrates for calcineurin. J Biol Chem 259:8080-8083.

Konnerth A, Dreessen J, Augustine GJ (1992) Brief dendritic calcium signals initiate long-lasting synaptic depression in cerebellar Purkinje cells. Proc Natl Acad Sci USA 89:7051-7055.

Lamb TD, Pugh Jr EN (1992) A quantitative account of the activation steps involved in phototransduction in amphibian photoreceptors. J Pliysiol (Lond) 449:719-758.

Levitan I, Hillman P, Payne R (1993) Fast desensitization of the response to InsP3 in Limulus ventral photoreceptors. Biophys J 64:1354-1360.

Linden DJ, Connor JA (1991) Participation of postsynaptic PKC in cercbellar long-term depression in culture. Science 254:1656-1659.

I inden DJ, Connor JA (1993) Cellular mechanisms of long-term depression in the cerebellum. Curr Opin Neurobiol 3:401-406.

Linden DJ, Dawson TM, Dawson VL (1995) An evaluation of the nitric oxide/cGMP/cGMP-dependent protein kinase cascade in the induction of cercbcllar long-term depression in culture. J Neurosci 15:5098-5105.

Linden DJ, Dickinson MH, Smeyne M, Conner JA (1991) A long-term depression of AMPA currents in cultured cerebellar Purkinje neurons. Neuron 7:81-89.

Linden DJ, Smeyne M, Connor JA (1993) Induction of cerebellar longterm depression in culture requires postsynaptic action of sodium ions. Neuron 11:1093-1100.

Linás R, Sugimori M (1992) The electrophysiology of the cerebellar Purkinje cell revisited. In: The cerebellum revisited (Llinás R, Sotelo $\mathrm{C}$, eds), pp 167-181. New York: Springer.

Lonart G, Alagarsamy S, Johnson KM (1993) (R,S)- $\alpha$-amino-3-hydroxy5-methylisoxazole-4-propionic acid (AMPA) receptors mediate a calcium-dependent inhibition of the metabotropic glutamate receptorstimulated formation of inositol 1,4,5-trisphosphate. J Neurochem 60:1739-1745.
Matzel LD, Schreurs BG, Lederhendler I, Alkon DL (1990) Acquisition of conditioned associations in Hermissenda: additive effects of contiguity and the forward interstimulus interval. Behav Neurosci 104:597-606.

McCormick DA, Thompson RF (1984) Neuronal responses of the rabbit cerebellum during acquisition and performance of a classically conditioned nictitating membrane-eyelid response. J Neurosei 4:2811-2822.

McCormick DA, Clark GA, Lavond DG, Thompson RF (1982) Initial localization of the memory trace for a basic form of learning. Proc Natl Acad Sci USA 79:2731-2735.

McGonigle P, Molinoff PB (1994) Receptors and signal transduction: classification and quantitation. In: Basic neurochemistry: molecular, cellular, and medical aspects, 5th ed (Siegel GJ, Agranoff BW, Albers RW, Molinoff PB, eds), pp 417-428. New York: Raven.

Meissner G, Darling E, Eveleth J (1986) Kinetics of rapid $\mathrm{Ca}^{2+}$ release by sarcoplasmic reticulum. Effects of $\mathrm{Ca}^{2+}: \mathrm{Mg}^{2+}$, and adenine nucle otides. Biochemistry 25:236-244.

Midtgaard J, Lasser-Ross N, Ross WN (1993) Spatial distribution of $\mathrm{Ca}^{2+}$ influx in turtle Purkinje cell dendrites in vitro: Role of a transient outward current. J Neurophysiol 70:2455-2469.

Mignery GA, Johnston PA, Südhof TC (1992) Mechanism of $\mathrm{Ca}^{2+}$ inhibition of inositol 1,4,5-trisphosphate $\left(\operatorname{Ins}_{3}\right)$ binding to the cerebellar InsP $_{3}$ receptor. J Biol Chem 267:7450)-7455.

Millenson JR, Kehoe EJ, Gormenzano I (1977) Classical conditioning of the rabbit's nictitating membrane response under fixed and mixed CS-US intervals. Learn Motiv 8:351-366.

Missiaen L, Parys JB, De Smedt H, Oike M, Castecls R (1994) Partial calcium release in response to submaximal inositol 1,4,5-trisphosphate receptor activation. Mol Cell Endocrinol 98:147-156.

Miyakawa H, Lev-Ram V, Lasser-Ross N, Ross WN (1992) Calcium transients evoked by climbing fiber and parallel fiber synaptic inputs in guinea pig cerebellar Purkinje ncurons. J Ncurophysiol 68:1178-1189.

Moore JW, Desmond JE, Berthier NE (1989) Adaptively timed conditioned responses and the cerebellum: a neural network approach. Biol Cybern 62:17-28.

Nagy K (1991) Biophysical processes in invertebrate photoreceptors: recent progress and a critical overview based on Limulus photoreceptors. Q Rev Biophys 24:165-226.

Nakanishi Y (1988) The molecular heterogeneity of protein kinase C and its implications for cellular regulation. Nature 334:661-665.

Nestler EJ, Duman RS (1994) G proteins and cyclic nucleotides in the nervous system. In: Basic neurochemistry: molecular, cellular, and medical aspects, 5th ed (Siegel GJ, Agranoff BW, Albers RW, Molinoff PB, eds), pp 429-448. New York: Raven.

Nestler EJ, Greengard P (1984) Protein phosphorylation in the nervous system. New York: Wiley.

Nishizuka Y (1986) Studies and perspectives of protein kinase C. Science 233:305-310.

Nishizuka Y (1988) The molecular helerogeneity of protein kinase $C$ and its implications for cellular regulation. Nature 334:661-665.

Nusser Z, Mulvihill E, Streit P, Somogyi P (1994) Subsynaptic segregation of metabotropic and ionotropic glutamate receptors as revealed by immunogold localization. Neuroscience 61:421-427.

Palay SL, Chan-Palay V (1974) Cerebellar cortex: cytology and organization. New York: Springer.

Perrett SP, Ruiz BP, Mauk MD (1993) Cerebellar cortex lesions disrupt learning dependent timing of conditioned cyelid responses. J Neurosei 13:1708-1718.

Reinhart PH, Levitan IB (1995) Kinase and phosphatase activities intimately associated with a reconstituted calcium-dependent potassium channel. J Neurosci 15:4572-4579.

Richard EA, Sampat P, Lisman JE (1995) Distinguishing between roles for calcium in Limulus photoreceptor excitation. Cell Calcium $18: 330-340$.

Sakurai M (1989) Depression and potentiation of parallel fiber-Purkinje cell transmission in in vitro cerebellar slices. In: Olivo-cerebellar system in motor control (Strata P, ed), pp 221-230. Berlin: Springer.

Sakurai M (1990) Calcium is an intracellular mediator of the climbing fiber in induction of cerebellar long-term depression. Proc Natl Acad Sci USA 87:3383-3385.

Schwartz JH, Kandel ER (1991) Synaptic transmission mediated by second messengers. In: Principles of neural science. 3rd ed (Kandel ER, Schwartz JH, Jessell TM, eds), pp 173-193. New York: Elsevier.

Shibuki K, Okada D (1991) Endogenous nitric oxide release required for long-term synaptic depression in the cerebellum. Nature 349:326-328. 
Shibuki K, Okada D (1992) Cerebellar long-term potentiation under suppressed postsynaptic $\mathrm{Ca}^{2+}$ activity. NeuroReport 3:231-234.

Shigemoto R, Abe T, Nomura S, Nakanishi S, Hirano T (1994) Antibodies inactivating mGluR1 metabotropic glutamate receptor block long-term depression in cultured Purkinje cells. Neuron 12:1245-1255.

Shigemoto R, Nakanishi S, Mizuno N (1992) Distribution of the mRNA for a metabotropic glutamate receptor (mGluR1) in the central nervous system: an in situ hybridization study in adult and developing rat. $\mathrm{J}$ Comp Neurol 322:121-135.

Shin J, Richard EA, Lisman JE (1993) $\mathrm{Ca}^{2+}$ is an obligatory intermediate in the excitation cascade of Limulus photoreceptors. Neuron 11:845-855.

Smith MC, Coleman SR, Gormezano I (1969) Classical conditioning of the rabbit's nictitating membrane response at backward, simultaneous, and forward CS-US intervals. J Comp Physiol Psychol 69:226-231.

Solomon PR, Vander Schaaf ER, Thompson RF, Weisz DJ (1986) Hippocampus and trace conditioning of the rabbit's classically conditioned nictitating membrane response. Behav Neurosci 100:729-744.

Staub C, Vranesic I, Knopfel T (1992) Responses to metabotropic glutamate receptor activation in cerebellar Purkinje cells: induction of an inward current. Eur J Neurosci 4:832-839.

Steinmetz JE (1990a) Classical nictitating membrane conditioning in rabbits with varying interstimulus intervals and direct activation of cerebellar mossy fibers as the CS. Behav Brain Res 38:97-108.

Steinmetz JE (1990b) Neuronal activity in the rabbit interpositus nuclcus during classical NM-conditioning with a pontine-nucleus-stimulation CS. Psychol Sci 1:378-382.

Steinmetz JE, Lavond DG, Thompson RF (1989) Classical conditioning in rabbits using ontine nucleus stimulation as a conditioned stimulus and inferior olive stimulation as an unconditioned stimulus. Synapse 3:225-233.

Steinmetz JE, Logan CG, Rosen DJ, Thompson JK, Lavond DG, Thompson RF (1987) Initial localization of the acoustic conditioned stimulus projection to the cercbellum essential for classical eyelid conditioning. Proc Natl Acad Sci USA 84:3531-3535.

Steinmetz JE, Rosen DJ, Chapman PF, Lavond DG, Thompson RF (1986) Classical conditioning of the rabbit eyelid response with a mossy fibcr stimulation CS: I. Pontinc nuclci and middlc ccrcbcllar peduncle stimulation. Behav Neurosci 100:878-887.

Stemmer PM, Klee CB (1994) Dual calcium ion regulation of calcineurin by calmodulin and calcineurin B. Biochemistry 33:6859-6866.
Takei K, Mignery GA, Mugnaini E, Südhof TC, De Camilli P (1994) Inositol 1,4,5-trisphosphate receptor causes formation of ER cisternal stacks in transfected fibroblasts and in cerebellar Purkinje cells. Neuron $12: 327-342$

Takci K, Stukcnbrok H, Metcalf A, Mignery GA, Südhof TC, Volpe P, De Camilli P (1992) $\mathrm{Ca}^{2+}$ stores in Purkinje neurons: endoplasmic reticulum subcompartments demonstrated by the heterogeneous distribution of the $\mathrm{InsP}_{3}$ receptor, $\mathrm{Ca}^{2+}$-ATPase, and calsequestrin. J Neurosci $12: 489-505$.

Thompson JH, Bower JM (1993) Electrophysiolngical dissection of the excitatory inputs to Purkinje cells. In: Computation and neural systems (Eeckman FH, Bower JM, eds), pp 349-353. Norwell, MA; Kluwer Academic Publishers.

Thompson RF (1990) Neural mechanisms of classical conditioning in mammals. Philos Trans R Soc Lond [Biol] 329:161-170.

Thompson RF, Krupa DJ (1994) Organization of memory traces in the mammalian brain. Annu Rev Neurosci 17:519-549.

Thomsen C., Mulvihill ER, Haldeman B, Pickering DS, Hampson DR, Suzdak PD (1993) A pharmacological characterization of the mGluR $1 \alpha$ subtype of the metabotropic glutamate receptor expressed in a cloned baby hamster kidney cell line. Brain Res 619:22-28.

Villa A, Podini P, Clegg DO, Pozzan T, Meldolesi J (1991) Intracellular $\mathrm{Ca}^{2+}$ stores in chicken Purkinje neurons: differential distribution of the low affinity-high capacity $\mathrm{Ca}^{21}$ binding protein, calsequestrin, of $\mathrm{Ca}^{2+}$ ATPase and of the ER lumenal protein, Bip. J Ccll Biol 113:779-791.

Wang SS-H, Alousi AA, Thompson SH (1995) The lifetime of inositol 1,4,5-trisphosphate in single cells. J Gen Physiol 105:149-171.

Watras J, Bezprozvanny I, Ehrlich BE (1991) Inositol 1,4,5-trisphosphategated channels in cerebellum: presence of multiple conductance states. J Neurosci 11:3239-3245.

Yamada WM, Koch C, Adams PR (1989) Multiple channels and calcium dynamics. In: Methods in neuronal modeling: from synapse to networks (Koch C, Segev I, eds), pp 97-133. Boston: MIT.

Yarfitz S, Hurley JB (1994) Transduction mechanisms of vertebrate and invertebrate photoreceptors. J Biol Chem 269:14329-14332.

Zipser D (1986) A model of hippocampal learning during classical conditioning. Behav Neurosci 100:764-776. 